\title{
\#USGS
}

science for a changing world

Prepared in cooperation with the U.SyEnvironmental Protection Agency

Trace Metal and Nutrient Loads from Groundwater Seepage into the South Fork Coetir d Alene River near Smelterville, Northern ldaho 2017

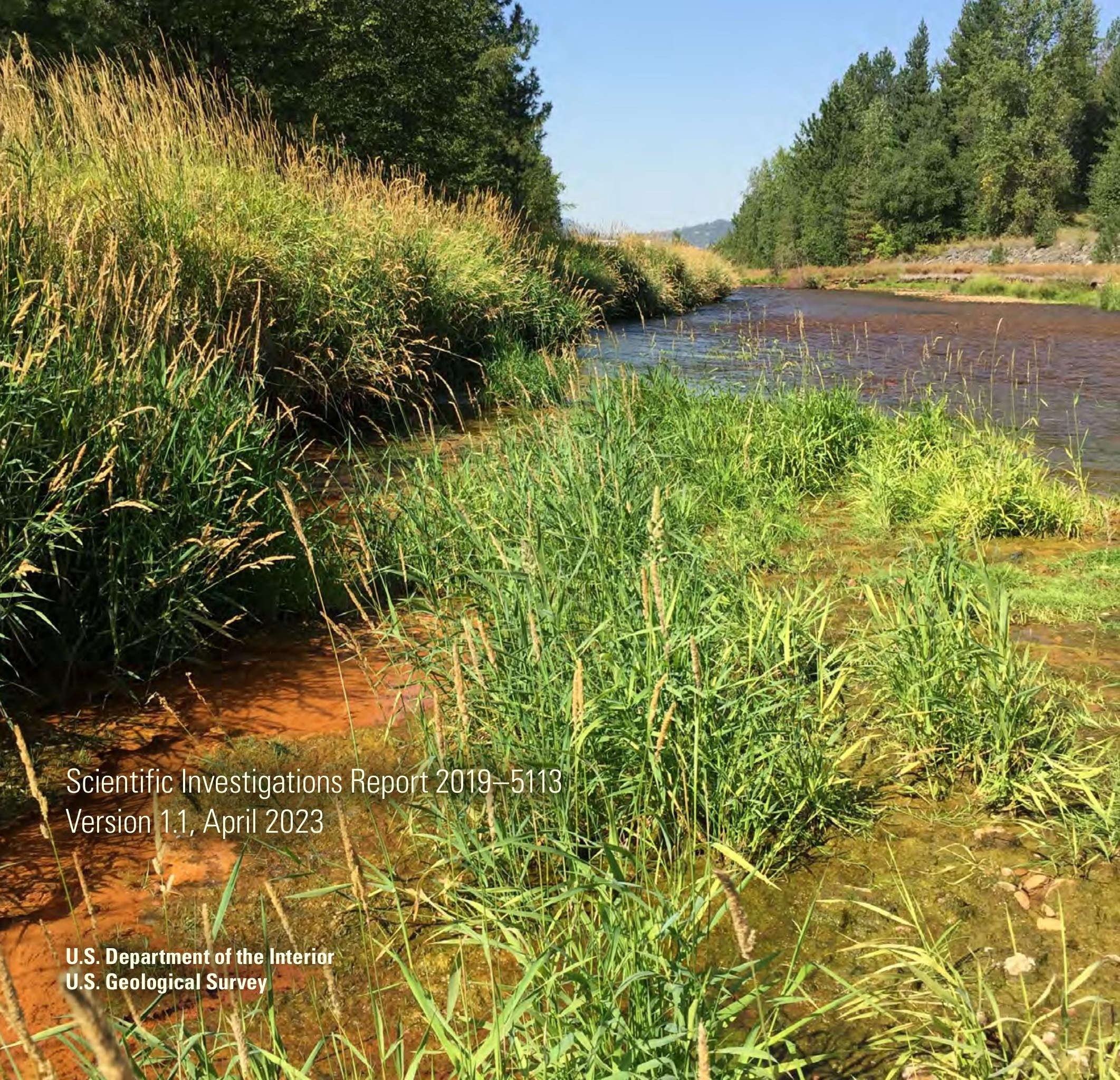


Front Cover: Iron staining associated with groundwater discharge to the South Fork Coeur d'Alene River between Kellogg and Smelterville, Idaho. Photograph by Lauren Zinsser, U.S. Geological Survey, August 16, 2016.

Back Cover: Looking southeast across the South Fork Coeur d'Alene River toward the Central Impoundment Area between Kellogg and Smelterville, Idaho. Photograph by Lauren Zinsser, U.S. Geological Survey, August 16, 2016. 


\section{Trace Metal and Nutrient Loads from Groundwater Seepage into the South Fork Coeur d'Alene River near Smelterville, Northern Idaho, 2017}

By Lauren M. Zinsser

Prepared in cooperation with the U.S. Environmental Protection Agency

Scientific Investigations Report 2019-5113

Version 1.1, April 2023 


\title{
U.S. Department of the Interior DAVID BERNHARDT, Secretary
}

\section{U.S. Geological Survey James F. Reilly II, Director}

\author{
U.S. Geological Survey, Reston, Virginia \\ First release: 2019 \\ Revised: April 2023 (ver. 1.1)
}

For more information on the USGS —-the Federal source for science about the Earth, its natural and living resources, natural hazards, and the environment-visit https://www.usgs.gov or call 1-888-ASK-USGS.

For an overview of USGS information products, including maps, imagery, and publications,

visit https://store.usgs.gov.

Any use of trade, firm, or product names is for descriptive purposes only and does not imply endorsement by the U.S. Government.

Although this information product, for the most part, is in the public domain, it also may contain copyrighted materials as noted in the text. Permission to reproduce copyrighted items must be secured from the copyright owner.

Suggested citation:

Zinsser, L.M., 2019, Trace metal and nutrient loads from groundwater seepage into the South Fork Coeur d'Alene River near Smelterville, northern Idaho, 2017 (ver. 1.1, April 2023): U.S. Geological Survey Scientific Investigations Report 2019-5113, 22 p., https://doi.org/10.3133/sir20195113.

ISSN 2328-0328 (online) 


\section{Contents}

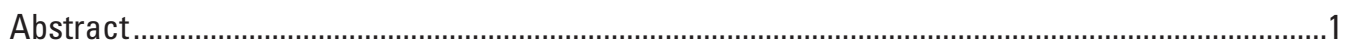

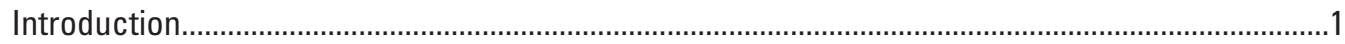

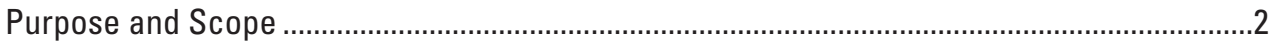

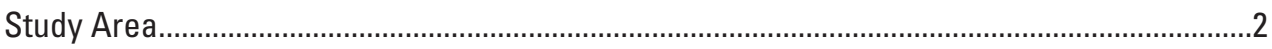

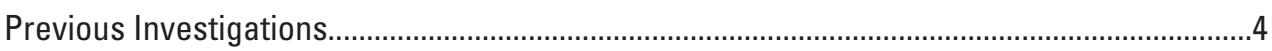

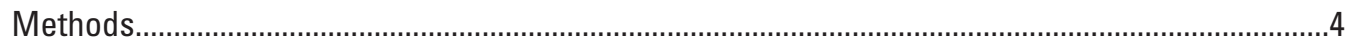

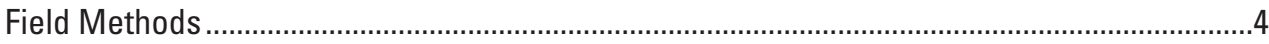

Constituent Load and Mass Balance Calculations ..................................................................6

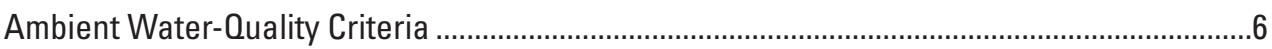

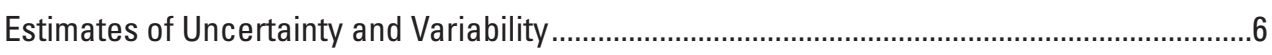

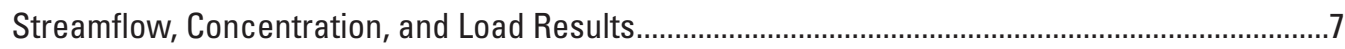

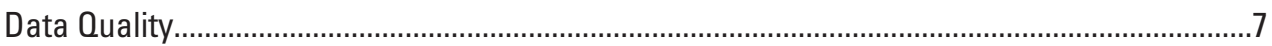

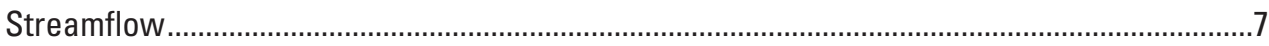

Zinc and Cadmium ......................................................................................................

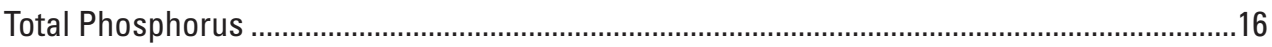

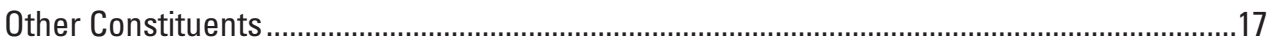

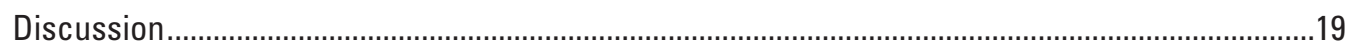

Summary

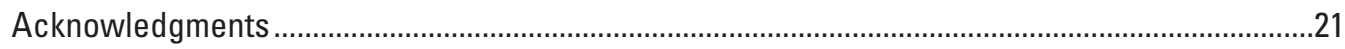

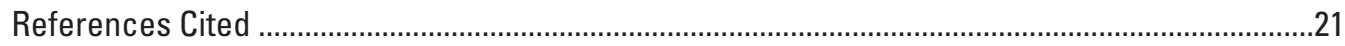

\section{Figures}

1. Maps showing general location and monitoring sites for the seepage study, in the Coeur d'Alene River Basin, northern Idaho .........................................................3

2. Graphs showing streamflow accruals as streamflow measurement and uncertainty, and mean streamflow and standard deviation, in the South Fork Coeur d'Alene River (SFCDR), northern Idaho

3. Graph showing mean dissolved zinc load accruals in the South Fork Coeur d'Alene River (SFCDR), northern Idaho

4. Graph showing dissolved zinc concentrations over time in the South Fork Coeur d'Alene River (SFCDR) and tributaries, northern Idaho, September 6-7, 2017.

5. Graph showing mean dissolved cadmium load accruals in the South Fork Coeur d'Alene River (SFCDR), northern Idaho.

6. Graph showing dissolved cadmium concentrations over time in the South ForkCoeur d'Alene River (SFCDR) and tributaries, northern Idaho, September 6-7, 2017

7. Graph showing mean total phosphorus load accruals in the South Fork Coeur d'Alene River (SFCDR), northern Idaho.

8. Graphs showing mean constituent concentrations in the South Fork Coeur d'Alene River (SFCDR), northern Idaho 


\section{Tables}

1. Seepage study monitoring sites, in the Coeur d'Alene River Basin, northern Idaho ........5

2. Individual measurement streamflows, concentrations, loads, and uncertainties for select constituents, in the Coeur d'Alene River Basin, northern Idaho

3. Mean streamflows, concentrations, loads, and standard deviations for select constituents, in the Coeur d'Alene River Basin, northern Idaho

4. Summary of site-specific zinc and cadmium ambient water-quality criteria and ratios, in the South Fork Coeur d'Alene River (SFCDR) and select tributaries, northern Idaho.

5. Summary of seepage study dissolved zinc and cadmium and total phosphorus load accruals from groundwater, 1999-2017

6. Summary of site-specific zinc and cadmium ambient water-quality criteria and ratios from area studies, 2008-17 


\section{Conversion Factors}

U.S. customary units to International System of Units

\begin{tabular}{|c|c|c|}
\hline Multiply & By & To obtain \\
\hline \multicolumn{3}{|c|}{ Length } \\
\hline mile (mi) & 1.609 & kilometer $(\mathrm{km})$ \\
\hline \multicolumn{3}{|c|}{ Area } \\
\hline square mile $\left(\mathrm{mi}^{2}\right)$ & 2.590 & square kilometer $\left(\mathrm{km}^{2}\right)$ \\
\hline acre & 0.004047 & square kilometer $\left(\mathrm{km}^{2}\right)$ \\
\hline \multicolumn{3}{|c|}{ Flow rate } \\
\hline cubic foot per second $\left(\mathrm{ft}^{3} / \mathrm{s}\right)$ & 0.02832 & cubic meter per second $\left(\mathrm{m}^{3} / \mathrm{s}\right)$ \\
\hline \multicolumn{3}{|c|}{ Concentrations and loads } \\
\hline pounds per day (lb/d) & 0.4536 & kilograms per day $(\mathrm{kg} / \mathrm{d})$ \\
\hline
\end{tabular}

International System of Units to U.S. customary units

\begin{tabular}{lcl}
\hline \multicolumn{1}{c}{ Multiply } & \multicolumn{1}{c}{ By } & \multicolumn{1}{c}{ To obtain } \\
\hline micrometer $(\mu)$ & Length & \\
\hline \multicolumn{2}{l}{0.0000393701} & inch $($ in.) \\
\hline kilograms per day $(\mathrm{kg} / \mathrm{d})$ & Concentrations and loads & \\
milligrams per liter $(\mathrm{mg} / \mathrm{L})$ & 2.205 & pound avoirdupois $(\mathrm{lb})$ \\
micrograms per liter $(\mu \mathrm{g} / \mathrm{L})$ & 0.000008345404 & pound per gallon $(\mathrm{lb} / \mathrm{gal})$ \\
& 0.001 & parts per million $(\mathrm{ppm})$ \\
\hline
\end{tabular}

\section{Datums}

Vertical coordinate information is referenced to the North American Vertical Datum of 1988 (NAVD 88).

Horizontal coordinate information is referenced to the North American Datum of 1983 (NAD 83).

Elevation, as used in this report, refers to distance above the vertical datum. 


\section{Supplemental Information}

Specific conductance is given in microsiemens per centimeter at 25 degrees

Celsius $\left(\mu \mathrm{S} / \mathrm{cm}\right.$ at $\left.25^{\circ} \mathrm{C}\right)$.

Concentrations of chemical constituents in water are given in either milligrams per liter (mg/L) or micrograms per liter ( $\mu \mathrm{g} / \mathrm{L})$.

\section{Abbreviations}

AWOC ambient water-quality criteria

CIA Central Impoundment Area

SFCDR South Fork Coeur d'Alene River

EPA U.S. Environmental Protection Agency

USGS U.S. Geological Survey 


\title{
Trace Metal and Nutrient Loads from Groundwater Seepage into the South Fork Coeur d'Alene River near Smelterville, Northern Idaho, 2017
}

\author{
By Lauren M. Zinsser
}

\section{Abstract}

The Coeur d'Alene mining district in northern Idaho historically was a globally important source of lead, zinc, and silver, but over 100 years of mining has left a legacy of metals contamination in the Coeur d'Alene River valley. Previous studies by the U.S. Geological Survey (USGS) and others have indicated that groundwater discharging into the South Fork Coeur d'Alene River between Kellogg and Smelterville, Idaho, is a substantial source of dissolved zinc, dissolved cadmium, and total phosphorus. As part of its ongoing cleanup efforts, the U.S. Environmental Protection Agency is constructing a groundwater collection and treatment system to intercept and treat this contaminated water before it reaches the river.

To establish conditions prior to construction, the USGS conducted a seepage study in September 2017 to quantify the rate and quality of groundwater discharging into the South Fork Coeur d'Alene River between Kellogg and Smelterville. Repeated measurements of streamflow were taken at multiple locations in the river and tributaries, and water-quality samples were collected and analyzed for trace metals and nutrients. Results showed consistent increases in streamflow (5.8 \pm 1.3 cubic feet per second); and in dissolved zinc ( $85 \pm 9.3$ kilograms per day $[\mathrm{kg} / \mathrm{d}])$, dissolved cadmium $(0.58 \pm 0.10 \mathrm{~kg} / \mathrm{d})$ and total phosphorus $(6.3 \pm 0.45 \mathrm{~kg} / \mathrm{d})$ loads in a discrete segment of the reach. These gains exceeded tributary inputs, thereby implicating groundwater discharge as the main source of loading. Zinc and cadmium loads from groundwater in 2017 were less than those measured in 1999 but comparable to those measured from 2003 to 2008. This suggests that remedial actions in the late 1990s and early 2000s decreased trace-metal loading from 1999 to 2003, but that conditions remained similar from 2003 to 2017. A second seepage study will be conducted after construction and treatment plant system optimization are complete; this second study will evaluate changes in groundwater discharge to and water quality in the South Fork Coeur d'Alene River compared to the pre-construction conditions.

\section{Introduction}

The Coeur d'Alene mining district in northern Idaho, once a globally important source of lead, zinc, and silver ore, has been mined since the 1880 s. Historical mining and ore-processing practices resulted in the direct deposition of mining waste materials in the South Fork Coeur d'Alene River (SFCDR) and its tributaries and floodplain. As a result of these practices, over 56 million metric tons of tailings with high concentrations of metals, including cadmium, zinc, and lead, were transported downstream; an additional 13.2 million metric tons were stockpiled along the SFCDR floodplain near Kellogg (Long, 1998). These metal-rich sediments are widely dispersed throughout the lower Coeur d'Alene River Basin, including through floodplains, riverbed sediments, wetlands, lateral lakes adjacent to the Coeur d'Alene River, at the bottom of Lake Coeur d'Alene, and downstream of the lake in the Spokane River (U.S. Environmental Protection Agency, 2002). The affected areas are designated as the Bunker Hill Mining \& Metallurgical Complex Superfund Site. This site was first added to the National Priorities List in 1983; since then, the site has undergone and continues to be the subject of multiple investigations and remedial activities to understand and clean up the complicated and extensive legacy of contamination throughout the basin (U.S. Environmental Protection Agency, 2012a).

During the summer of 2018, the U.S. Environmental Protection Agency (EPA) began work on a remedial action at the Central Impoundment Area (CIA) between the towns of Kellogg and Smelterville. Now encompassing over 200 acres, the CIA originally was an unlined repository for tailings from the Bunker Hill Mine mills and waste from the lead smelter and zinc plant, but it now contains jig and flotation tailings; and slimes, gypsum, smelter slag, and other process waste (CH2M HILL, 2006). In 2000, the EPA completed an engineered cover system that included a geomebrane to cut off infiltration of precipitation into the mine waste contained within the CIA and contouring the top of it (U.S. Environmental Protection Agency, 2005). Previous 
investigations have interpreted substantial dissolved zinc and cadmium loading to the SFCDR as originating in groundwater discharging to the river from under the CIA (Barton, 2002; CH2M HILL, 2009a; Clark and Mebane, 2014). The ongoing remedial action will install a bentonite slurry wall underground on the downgradient side of the CIA to intercept groundwater; this groundwater will be pumped to the Central Treatment Plant (an existing facility that as of 2019 primarily treats acid mine drainage flow from the Bunker Hill Mine), which is being upgraded to handle the additional flow. Treated acid mine drainage flow from the Bunker Hill Mine and treated groundwater will then be discharged directly to the SFCDR (CH2M, 2018).

\section{Purpose and Scope}

The U.S. Geological Survey (USGS) conducted the 2017 seepage study in the SFCDR between Kellogg and Smelterville to quantify existing base-flow loading of dissolved metals and nutrients to the SFCDR prior to the implementation of the CIA remedial action. In this study area, "seepage study" has been used to describe investigations encompassing groundwater discharge to surface water and surface-water recharge of groundwater that occurs in the SFCDR (Barton, 2002; CH2M HILL, 2009a). This report follows this terminology convention and documents the methods used in and results of the 2017 seepage study. It is beyond the scope of this study to explore specific metal and nutrient release and transport mechanisms within the system. The USGS and EPA plan to repeat this seepage study following the optimization of operations of the groundwater collection system and upgraded Central Treatment Plant to better understand the direct effect of that remedial action on the quality and quantity of groundwater discharge to the SFCDR in this area. The results of this study, therefore, will provide important information for pre- and post-remedy waterquality comparisons.

\section{Study Area}

The Coeur d'Alene River Basin is about 1,453 $\mathrm{mi}^{2}$ in area and stretches across the Idaho panhandle from the Montana border on the east to Coeur d'Alene Lake on the west. Coeur d'Alene Lake discharges to the Spokane River near the western boundary of Idaho (fig. 1). The basin is forested and mountainous with narrow valleys; elevation ranges from about 2,100 to 6,800 feet, with a mean elevation of 3,740 feet (U.S. Geological Survey, 2018). Peak streamflows generally occur in the spring during snowmelt runoff. However, warm winter Pacific storms can cause significant rain-on-snow events in the winter and result in widespread flooding and transport of higher concentrations of sediment-bound trace metals including particulate lead. In contrast, dissolved zinc and cadmium concentrations generally are highest during late summer and early fall base-flow conditions, indicating the groundwater origin of these contaminants (Clark and Mebane, 2014).

The seepage study focused on the SFCDR between Kellogg and Smelterville and north of Interstate 90 and the CIA, along a 2.5-mile stretch of the SFCDR. The SFCDR channel is dynamic and braided through the upper two-thirds of this reach, and straighter and more channelized in the lower one-third. There is a sizeable marshy area between the interstate and the river channel about halfway through the reach (fig. $1 B$ ).

The study reach is approximately centered in the Bunker Hill "Box", a 21-mi area containing several towns; the SFCDR and its floodplain; and the former industrial mining complex that included the Bunker Hill mine and mill, a lead and zinc smelter, and a phosphoric acid and fertilizer plant (U.S. Environmental Protection Agency, 1992). Primary sources of contamination in the valley include tailings dispersed in the floodplain, riverbed, and banks; waste rock; concentrates; and mining wastes intentionally placed as fill for infrastructure such as railways and roads (U.S. Environmental Protection Agency, 1992, 2012a).

Groundwater-level monitoring and a groundwater model developed for the area generally indicate that (1) groundwater flow mimics topography, and (2) most valley floor groundwater occurs in alluvial sand and gravel aquifers above and below a confining silt-clay unit associated with the main-stem SFCDR valley. Seasonal recharge occurs through infiltration of precipitation and particularly during spring snowmelt, resulting in higher groundwater levels during spring and early summer. Groundwater is discharged to the SFCDR in some reaches (gaining stream) and recharged by the SFCDR in other reaches (losing stream). A groundwater model developed for the area shows groundwater discharge to the SFCDR throughout most of the study reach year-round, with seasonally intensified losing reaches at the far upstream and downstream ends (U.S. Environmental Protection Agency, 2012b; CH2M, 2018). 
$\boldsymbol{A}$
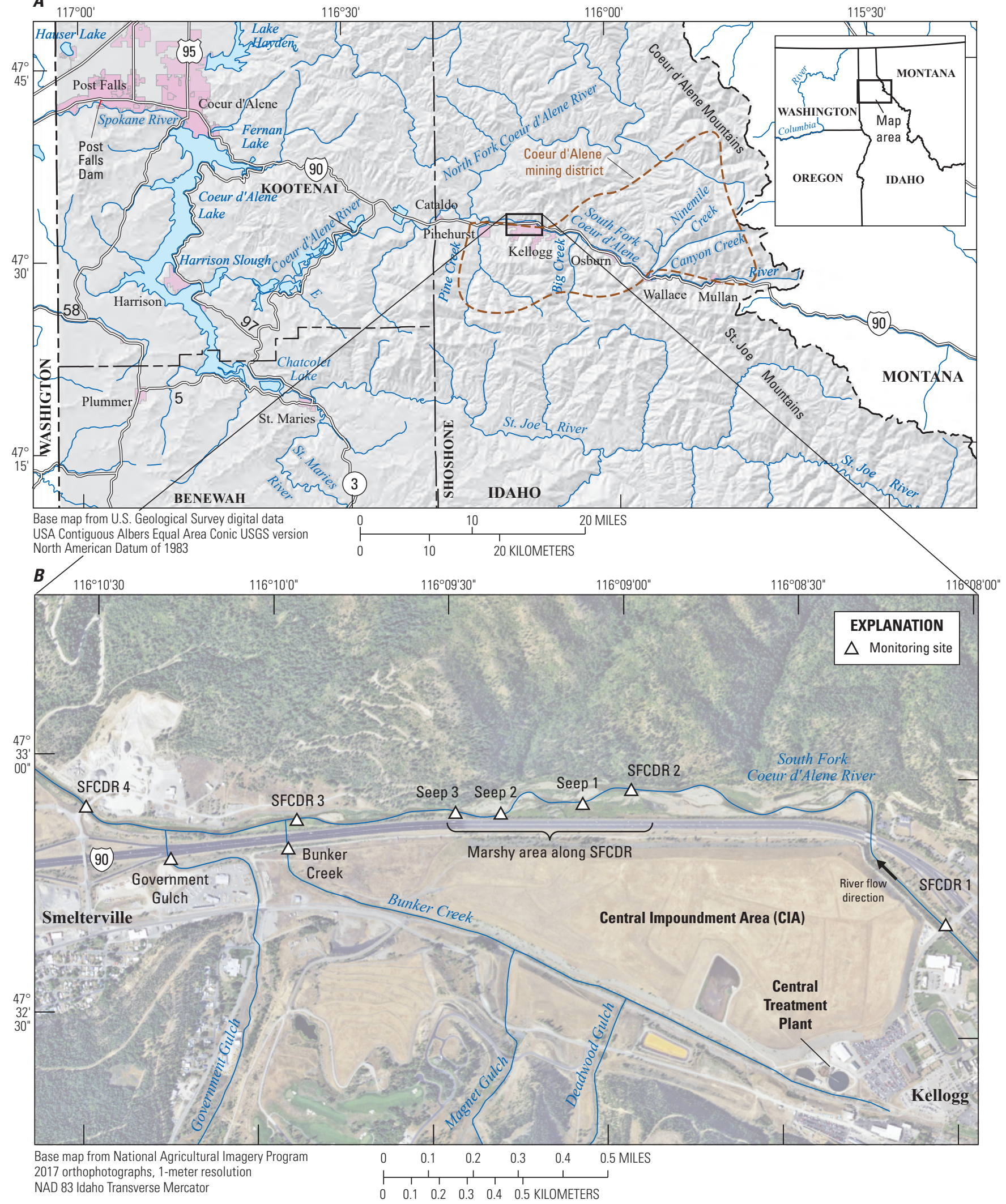

Figure 1. General location $(A)$ and monitoring sites $(B)$ for the seepage study, in the Coeur d'Alene River Basin, northern Idaho. Monitoring site names shown in this figure refer to the short names used for brevity in this report; see table 1 for site numbers and formal site names. 
The CIA has evolved over time as a waste repository, but is unlined and was built on previously deposited tailings; the base of the pile likely is below the groundwater table or at least within the zone of seasonal groundwater level fluctuations (CH2M, 2018). Thus, groundwater in contact with the base of the CIA wastes that subsequently discharges to the SFCDR is an important source of dissolved zinc and cadmium contamination in the study area. Substantial loading of total phosphorus to the SFCDR also occurs between Kellogg and Smelterville (Clark and Mebane, 2014). A historical phosphoric acid and fertilizer plant located about 0.5 mile upstream on Government Gulch produced phosphorus wastes that were impounded in several unlined impoundments on the south and west sides of the CIA. Infiltration from these impoundments into groundwater likely has contributed to localized high phosphorus concentrations in groundwater that are then released to the SFCDR through groundwater discharge (U.S. Environmental Protection Agency, 2012b; CH2M, 2018). Although total phosphorus is not identified as a contaminant of concern for the site (U.S. Environmental Protection Agency, 1992), managing phosphorus inputs to Coeur d'Alene Lake is a fundamental goal for maintaining lake water quality (Idaho Department of Environmental Quality and Coeur d'Alene Tribe, 2009). Thus, this seepage study focused on quantifying trace metal (dissolved zinc and cadmium) and nutrient (total phosphorus) loading in the reach, although multiple other constituents also were measured.

\section{Previous Investigations}

The USGS conducted a series of seepage studies in spring snowmelt recession and base-flow conditions in the SFCDR between Kellogg and Smelterville and at several other locations in July, September, and October 1999 (Barton, 2002). Among other findings, Barton (2002) measured gaining and losing SFCDR reaches between Kellogg and Smelterville (approximately sites $\mathrm{C} 3$ to $\mathrm{C} 6$ in the Barton study) and showed that groundwater discharge to the SFCDR in the gaining reach was a consistently high source of dissolved zinc (average $560 \mathrm{lb} / \mathrm{d}$ ) and dissolved cadmium (average $1.7 \mathrm{lb} / \mathrm{d}$ ) loading. CH2M HILL repeated the Barton seepage study for the Kellogg-to-Smelterville reach (approximately sites BH-SF-LF0003 to BH-SF-LF0006 in the CH2M HILL study) in calendar years 2003, 2006, 2007, and 2008. The loads varied from year to year, with the average dissolved zinc load from groundwater ranging from 140 to $315 \mathrm{lb} / \mathrm{d}$, and the average dissolved cadmium load ranging from 0.8 to $2.4 \mathrm{lb} / \mathrm{d}$ (CH2M HILL, 2009a). In the CH2M HILL and USGS studies, there was no measurable gain in dissolved lead load from groundwater, and neither study measured total phosphorus except for CH2M HILL in their final (2008) study
(Barton, 2002; CH2M HILL, 2009a). In 2008, the average groundwater loading of total phosphorus was $18 \mathrm{lb} / \mathrm{d}$ (CH2M HILL, 2009a).

On a broader spatial and temporal scale, since 2004 the USGS has conducted surface-water monitoring throughout the Coeur d'Alene River Basin and into the upper Spokane River as part of the Basin Environmental Monitoring Program. Clark and Mebane (2014) used this extensive dataset, as well as earlier sporadic sampling in the basin, to describe temporal trends in water quality and patterns in spatial loading. Among other findings, they identified substantial annual loading of dissolved zinc, dissolved cadmium, and total phosphorus to the SFCDR between Kellogg and Smelterville. However, this loading represented only a fraction of the annual trace metal loads (about 20-30 percent) and nutrient loads (about 11 percent) ultimately delivered to Coeur d'Alene Lake (Clark and Mebane, 2014)

Finally, Nimick and others (2003) reported the widespread occurrence of diel cycles in dissolved-metal concentrations in streams, including at a site on the SFCDR several miles downstream of Smelterville. These changes can be substantial; Nimick and others (2003) reported a 58-percent change in dissolved zinc concentrations, with the maximum occurring in the morning (0500-0800 hours) and the minimum occurring in late afternoon (1700-1800 hours). Although this work post-dated the seepage study by Barton (2002), a 2008 study by CH2M HILL (2009b) incorporated an investigation of diel effects on seepage upstream of the study reach and normalized loading accordingly. However, possibly because of cloudy conditions that can suppress diel cycles of temperature and $\mathrm{pH}$, and thereby affect cation adsorption and desorption (Nimick and others, 2003), the 2008 study measured smaller diel changes in dissolved zinc ( 23 percent) than the previous study, with the maximum at 0645 hours and the minimum at 1845 hours (CH2M HILL, 2009b).

\section{Methods}

\section{Field Methods}

The seepage study took place September 5-7, 2017, during base-flow conditions. The first day was devoted to field reconnaissance, including identifying locations with the best cross sections for streamflow measurements and verifying seep sampling locations. Sampling was conducted during the following 2 days. On September 6, field staff took streamflow and seepage discharge measurements and collected waterquality samples (1) once at four SFCDR sites, (2) once at two tributary sites, and (3) three times at three seeps (table 1). 
Table 1. Seepage study monitoring sites, in the Coeur d'Alene River Basin, northern Idaho.

[Short site names are used for brevity throughout this report. Abbrevations: abv, above; Crk, Creek; ID, Idaho; R, River; SF, South Fork; SFCDR, South Fork Coeur d'Alene River]

\begin{tabular}{lllllc}
\hline \multicolumn{1}{c}{ Site number } & \multicolumn{1}{c}{ Site name (formal) } & Site name (short) & Latitude & Longitude & River mile \\
\hline 12413250 & SF Coeur d'Alene R (at Bunker Ave) at Kellogg ID & SFCDR 1 & 47.5453 & -116.1342 & 0 \\
473256116084001 & SF Coeur d'Alene R abv north side seepage site & SFCDR 2 & 47.5494 & -116.1493 & 0.9 \\
473256116090601 & SF Coeur d'Alene R south side seepage site 1 & Seep 1 & 47.5489 & -116.1516 & 1 \\
473255116092001 & SF Coeur d'Alene R south side seepage site 2 & Seep 2 & 47.5485 & -116.1555 & 1.2 \\
473254116092701 & SF Coeur d'Alene R south side seepage site 3 & Seep 3 & 47.5485 & -116.1577 & 1.3 \\
473253116095501 & SF Coeur d'Alene River abv Bunker Crk & SFCDR 3 & 47.5481 & -116.1652 & 1.7 \\
473252116095301 & Bunker Creek at mouth of culvert at Kellogg, ID & Bunker Creek & 47.5472 & -116.1656 & 1.71 \\
473251116101701 & Government Gulch Crk at SF Cour d'Alene River, ID & Government Gulch & 47.5467 & -116.1712 & 2 \\
12413300 & SF Coeur d'Alene R at Smelterville ID & SFCDR 4 & 47.5483 & -116.1753 & 2.2 \\
\hline
\end{tabular}

Stream water-quality samples were collected from about 0900 to 1300 hours; seep water-quality samples were collected from about 1200 to 1530 hours. On September 7, field staff focused on the reach bracketing the seeps and tributaries, collecting streamflow measurements and water-quality samples three times at three SFCDR sites and two tributary sites. Water-quality samples were collected from about 0830 and 1630 hours. The objective of this sampling strategy was to collect multiple samples from each location over 2 days to determine variability within sites while maximizing sampling at key locations. The multiple measurements allowed better interpretation of overall system changes by specifically quantifying variability.

At each SFCDR and tributary site, cross sections were established once at the beginning of the study and then used for each streamflow measurement and water-quality sample collection event. Whenever possible, the same personnel used the same equipment to measure streamflow and to collect samples for a given site to reduce variability. Streamflow measurements were made using a top-setting wading rod and a YSI Sontek FlowTracker ${ }^{\circledR}$ acoustic Doppler velocimeter. Measurements were taken according to standard USGS procedures (Rantz, 1982; Turnipseed and Sauer, 2010).

Seeps 1 and 2 were identified in the marshy area during reconnaissance as locations where diffuse marsh seep flow concentrated into a discrete, quasi-channel and entered the SFCDR. Seep 3 was identified by a distinctive periphyton and iron flocculate layer on the river cobbles at the edge of the channel. Water at the three seep sites also had high specific conductivities, substantially greater than the range of the SFCDR. Flow for seeps 1 and 2 was estimated by taking a velocity measurement in the center of the most concentrated area of flow and estimating the cross-sectional area. Flow at seep 3 was diffuse through river gravels, and so was approximated by taking the average of the flow at seeps 1 and 2 to give an order of magnitude estimate of flow. Uncertainty associated with these measurements was estimated according to professional judgment but was considered high because of the difficulty of measuring diffuse flow through a marsh.
Water-quality samples in the SFCDR and tributaries were collected using a DH-81 sampler with a bottle and width- and depth-integrated methods as described in U.S. Geological Survey (various dates). Integrated samples were composited in a churn splitter prior to sample processing. Seep samples were collected as grab samples using an open-mouthed bottle owing to low sample depths and (or) velocities. Water-quality samples were processed onsite within 1 hour of collection according to locally modified one-person clean-hands-dirtyhands methods (Clark and Perreault, 2017; U.S. Geological Survey, various dates). Samples for dissolved analyses were filtered through a 0.45 -micrometer pore-size capsule filter. Samples for nutrient analyses were preserved with sulfuric acid and chilled; samples for trace-metal analyses were preserved with nitric acid. Samples were analyzed by the USGS Cascades Volcano Observatory Sediment Lab (Vancouver, Washington) for total suspended sediment and by the USGS National Water Quality Laboratory (Lakewood, Colorado) for all other measured analytes. Measured analytes were nutrients (organic nitrogen, ammonia, nitrate plus nitrite, total and dissolved phosphorus, and orthophosphate), major cations (magnesium and calcium), trace metals (total and dissolved arsenic, cadmium copper, iron, lead, manganese, and iron) and suspended-sediment concentration. On-site water-quality measurements of $\mathrm{pH}$, specific conductance, and water temperature were made with a Hydrolab Quanta multiparameter sonde.

To assess analytical data quality, one split replicate and one equipment blank were collected according to standard procedures (U.S. Geological Survey, various dates). The split replicate was withdrawn from the churn splitter after the parent sample and was analyzed separately at the laboratory. The split replicate provided an evaluation of variability in the sample splitting, filtering, and laboratory analysis processes. The equipment blank was collected by pouring laboratorycertified inorganic blank water into the sampler and then processing the water through the churn splitter and filtering line. This sample provided an assessment of variability in the sample collection and processing, equipment cleaning procedures, transport, and laboratory analysis (Mueller and others, 2015). 


\section{Constituent Load and Mass Balance Calculations}

Loads (mass per unit time) were calculated using point-in-time concentrations and streamflow measurements. However, the common assumption is made that point-intime concentrations and streamflow remain stable across daily time steps and, therefore, loads are expressed as daily totals (eq. 1). Both kilograms per day and pounds per day are used to describe loads in this report; kilograms per day are used for consistency with laboratory water-quality data that conventionally use metric units, and pounds per day are used for direct comparison with external datasets using these units.

$$
\text { Load }=Q \times C \times 2.447,
$$

where

Load is mass per unit time, in kilograms per day;

$Q \quad$ is streamflow, in cubic feet per second;

$C$ is concentration, in milligrams per liter; and

2.447 is a unit conversion constant for calculating daily load.

The seepage study was designed to use a water-balance approach to estimate groundwater exchange with surface water, which is difficult to measure directly. This approach generally measures streamflow and concentrations at successive points from upstream to downstream (differential discharge) in a river while identifying and measuring discrete inflows and outflows throughout the reach. The net change (accrual) from upstream to downstream, after accounting for the measured inflows and outflows, is inferred to represent groundwater inflow (gain) or outflow (loss) (Riggs, 1972). For this study, the effects of evapotranspiration were ignored because they were expected to be relatively small, and no diversions were identified in the reach. The following water balance (eq. 2) was used to calculate accrual, in cubic feet per second, between successive sites on the SFCDR (Simonds and Sinclair, 2002).

$$
\text { Net flow gain or loss }=Q_{d}-T-Q_{u}+D \text {, }
$$

where

$Q_{d} \quad$ is the streamflow measured at the downstream end of the reach, in cubic feet per second;

$Q_{u} \quad$ is the streamflow measured at the upstream end of the reach, in cubic feet per second;

$T$ is the sum of tributary inflows, in cubic feet per second; and

$D \quad$ is the sum of the diversion outflows, in cubic feet per second.

This equation was similarly applied to calculate accrual in constituent loads in the reach by substituting upstream, downstream and tributary loads (from eq. 1) for the streamflow variables $\left(Q_{d}, Q_{\nu}, T\right.$, and $\left.D\right)$ to yield load accrual (net load gain or loss). Tracer injection methods have been successfully used in other mining-affected streams to quantify diffuse flow and metal loads (Kimball and others, 2002).

However, despite the difficulty making flow measurements for the seeps in this system, the differential discharge method was used for comparability with the previous studies conducted by Barton (2002) and CH2M HILL (2009a).

In this report, significant figures are used to report calculated quantities in most cases, unless the use of significant figures implies precision for a calculation that is not supported by the precision of the underlying analytical or streamflow measurement. Furthermore, laboratory analytical precision can vary between samples and constituents. Thus, reported and calculated quantities may vary in significant figures based on the precision of the underlying measurements.

\section{Ambient Water-Quality Criteria}

In addition to loads, ambient water-quality criteria (AWQC) ratios were calculated for zinc and cadmium based on chronic criteria for aquatic life. The AWQC for these metals depends on hardness and also are specifically defined for the SFCDR; thus, they vary from the standard State of Idaho values (Idaho Department of Environmental Quality, various dates). The AWQC were calculated individually for each site based on the study-average water hardness for that site. Because the actual concentrations of zinc and cadmium greatly exceed the AWQC (Clark and Mebane, 2014), AWQC ratios were calculated by dividing the study-average site concentrations by the site-specific AWQC to give a better sense of the level of exceedance relative to other sites.

\section{Estimates of Uncertainty and Variability}

Careful consideration of the magnitude of uncertainty and variability is important for seepage studies because the net change is not directly measured but is estimated based on other measurements. As such, small changes can be obscured by high measurement uncertainty and (or) site variability, or large changes can fail to account for inherent uncertainty and (or) variability. In this study, uncertainty was quantified associated with each measurement, whereas variability quantified the range of measurements for a given site and analyte over the full study.

Uncertainty associated with each streamflow measurement was calculated by the FlowTracker ${ }^{\circledR}$ according to USGS statistical procedures (U.S. Geological Survey, 2017) and recorded in conjunction with the measured streamflow value. For net streamflow accrual, measurement uncertainties were propagated according to the simplified standard error propagation formula $(\mathrm{Ku}, 1966)$ : 


$$
s=\sqrt{( \pm a)^{2}+( \pm b)^{2} \ldots+( \pm n)^{2}}
$$

where

$s \quad$ is the error propagated from all estimated individual errors; and

$a, b, \ldots, n$ are the estimated errors for the streamflow measurement at each site.

Uncertainty associated with analytical results was estimated by using the duplicate sample results at SFCDR 1 to calculate relative sample difference for a given analyte. Relative sample difference is the absolute value of the difference between the two results, divided by the average of the two results, multiplied by 100 for expression as a percent. This percent uncertainty was applied to other site results for the same analyte to estimate uncertainty. For loads, uncertainties from streamflow and analytical measurements were propagated according to equation 3 . Finally, estimates of centrality and variability associated with streamflow and analytical measurements over the period of the study were calculated for each site as mean and standard deviation.

\section{Streamflow, Concentration, and Load Results}

\section{Data Quality}

Analytical results for the equipment blank were at or below method reporting limits for the analyzed constituents. This result indicates that field cleaning procedures were sufficient to decontaminate sampling equipment between samples. Split replicate analytical results for most constituents had relative sample differences of less than 5 percent. Some constituents that occur at low concentrations (ammonia, total and dissolved arsenic, and dissolved copper) had higher relative sample differences (12-30 percent for the metals and 67 percent for ammonia). As described in section, "Methods," the relative sample differences are incorporated into estimates of overall variability for concentration and load data; therefore, higher differences inform interpretations. Overall, the data quality results indicate that the collected data accurately characterize concentrations and are suitable for the analyses and interpretations presented here.

Measurement uncertainty and site variability were assessed. Uncertainty is used here to describe measurement error, which includes components of random and systematic error (Mueller and others, 2015). Variability is used to describe the range of conditions measured at a site over the study; this variability is influenced by measurement uncertainty and environmental changes (such as diel fluctuations in metals and streamflow). For streamflow measurements at most sites, measurement uncertainty generally was similar to the site standard deviation (tables 2 and 3, fig. $2 A$ and $2 B$ ), but propagated uncertainty associated with streamflow accrual calculations was greater than the accrual standard deviation (although similar in magnitude). This indicates partly the high uncertainty assigned to the seep flow estimates and partly the amplifying nature of error propagation for accrual calculations that inherently rely on multiple streamflow measurements.

At the relatively low concentrations and loads associated with total phosphorus, propagated uncertainty associated with streamflows generally caused load accrual uncertainty to be somewhat larger than (but similar in magnitude to) the load accrual standard deviation. However, for the large concentrations and loads associated with dissolved zinc and cadmium, load accrual standard deviations generally were larger than (but similar in magnitude to) the propagated load uncertainty (tables 2 and 3). Given that uncertainty and standard deviation were of similar magnitude, and that standard deviation incorporates elements of both inherent error and environmental change, means and standard deviations are used throughout this report to describe site trends.

\section{Streamflow}

Streamflow accrual (net change after accounting for inputs) was about equal to the variability between SFCDR 1 and SFCDR 2 and between SFCDR 3 and SFCDR 4 (tables 2 and 3 , fig. $2 A$ and $2 B$ ). Streamflow accrual consistently increased between SFCDR 2 and SFCDR $3\left(5.8 \pm 1.3 \mathrm{ft}^{3} / \mathrm{s}\right.$, mean \pm standard deviation; table 3 and fig. $2 B$ ). This reach (SFCDR 2 to SFCDR 3) is adjacent to the marshy area shown in figure 1. Therefore, total streamflow increase $\left(6.0 \pm 1.4 \mathrm{ft}^{3} / \mathrm{s}\right.$, mean \pm standard deviation) exceeded measured combined seep inputs $\left(0.75 \pm 0.38 \mathrm{ft}^{3} / \mathrm{s}\right.$, measurements \pm uncertainty) in the reach adjacent to the marshy area. In contrast, net streamflow change was less than the tributary inputs between SFCDR 3 and SFCDR 4, indicating this is likely a losing reach (although the loss was equal to the variability). This indicates that the major zone of groundwater flow into the SFCDR, representing about a 7 percent increase in streamflow, occurred in the reach adjacent to the marshy area, between SFCDR 2 and SFCDR 3. 


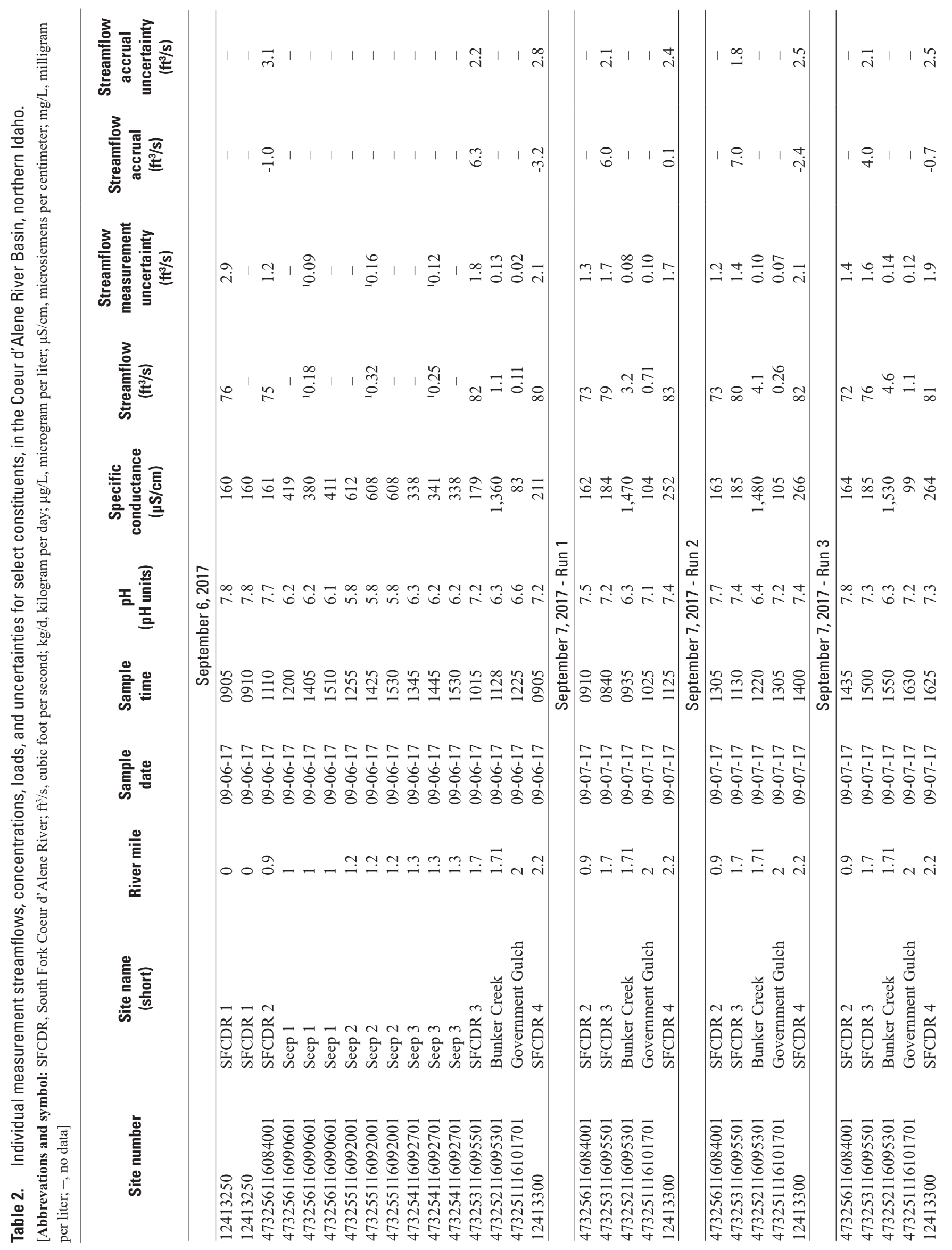




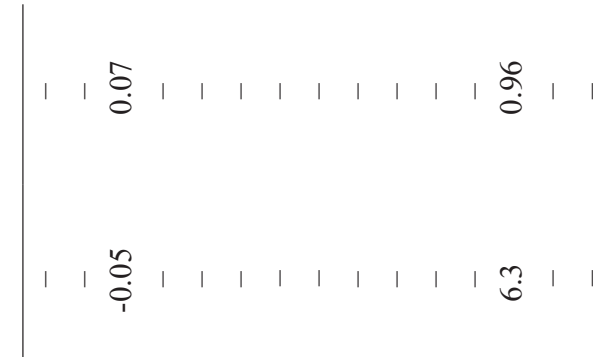

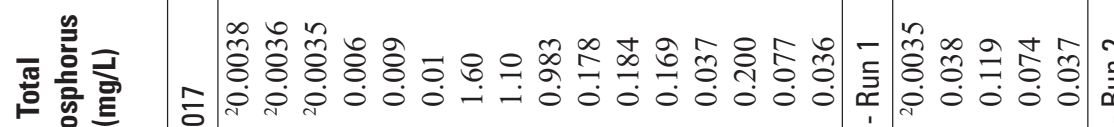

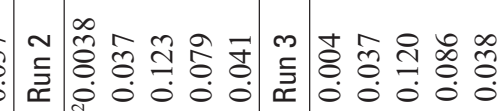

ธิ ธิ ชิ

을 일

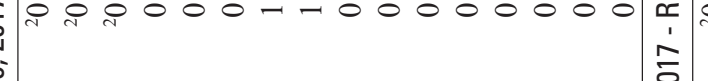
空 象

产 क

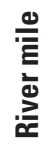

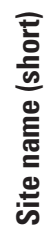
o

\section{六}

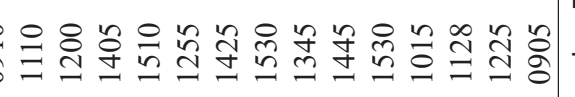

这

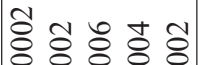

ิํㅇㅇํㅇํㅇ ชิ

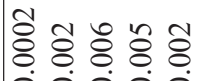

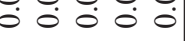
$\therefore \circ 0.0$

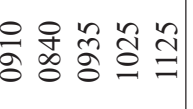

훙 $\bar{\varnothing} \vec{\circ}$

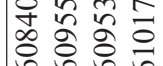

을 음 8

ज访云

帒究

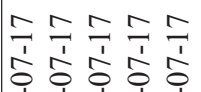

ó

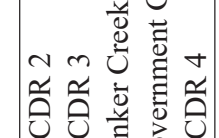

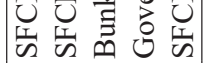

$$
\text { (2) }
$$

बำ

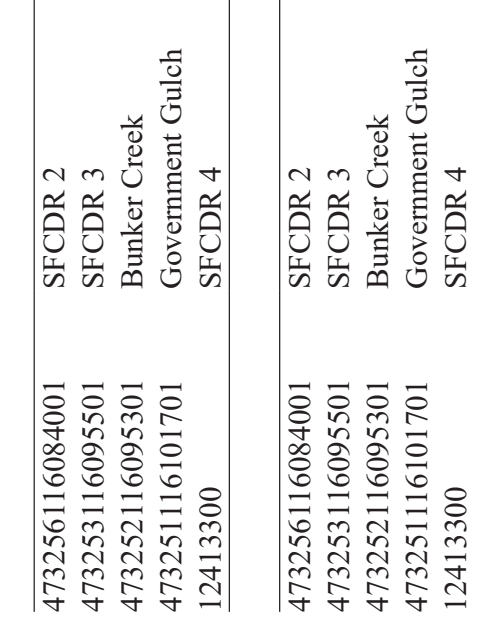




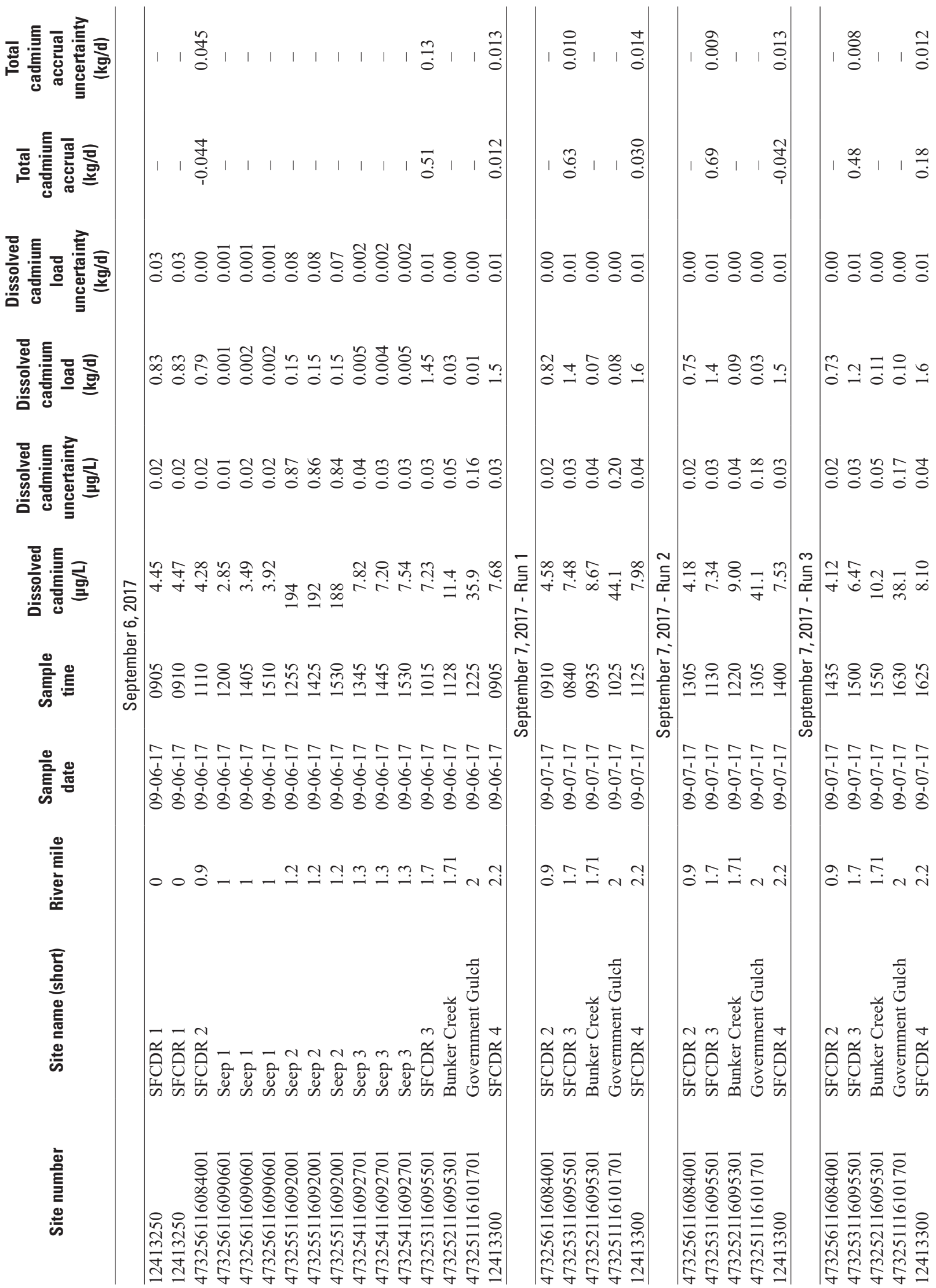




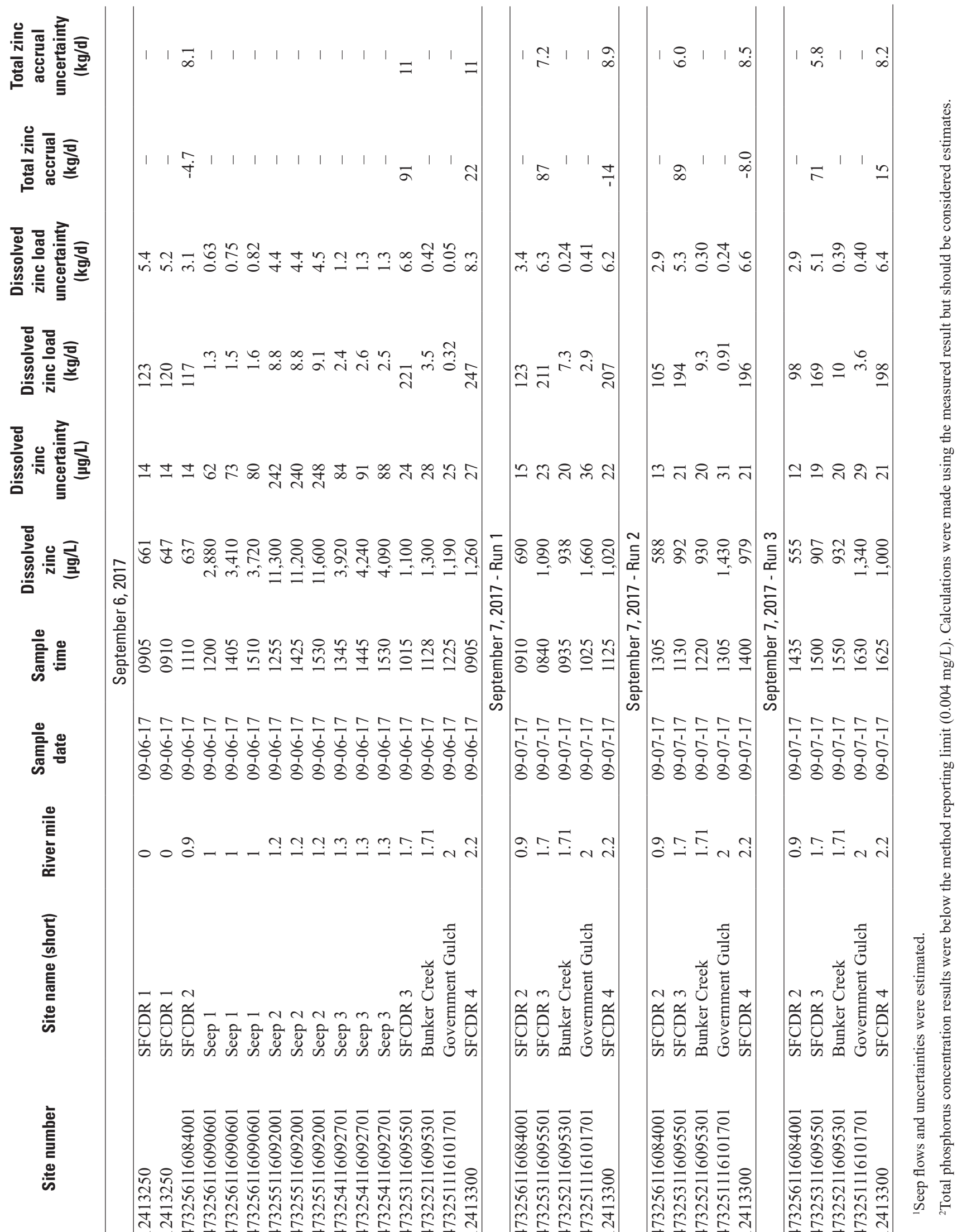



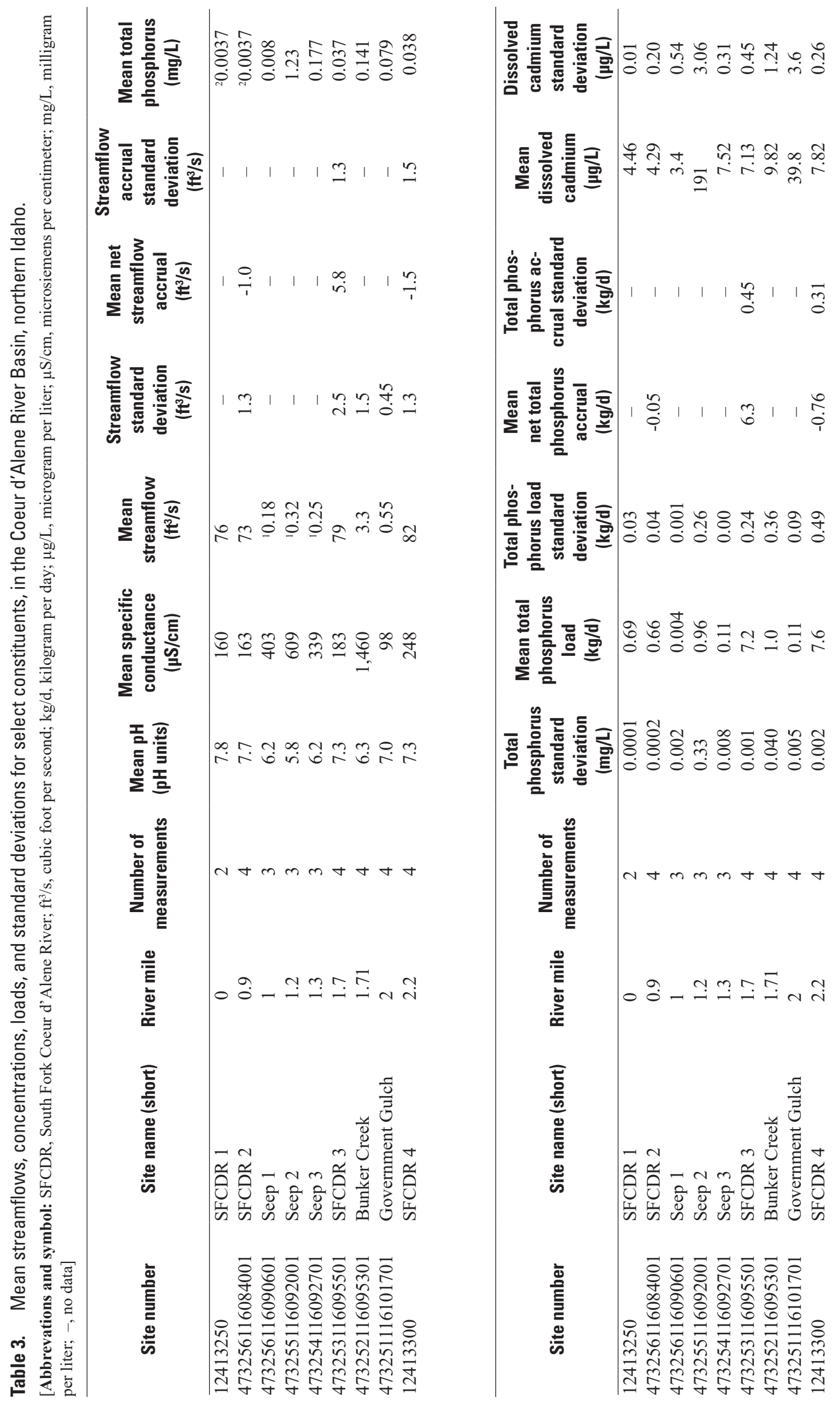

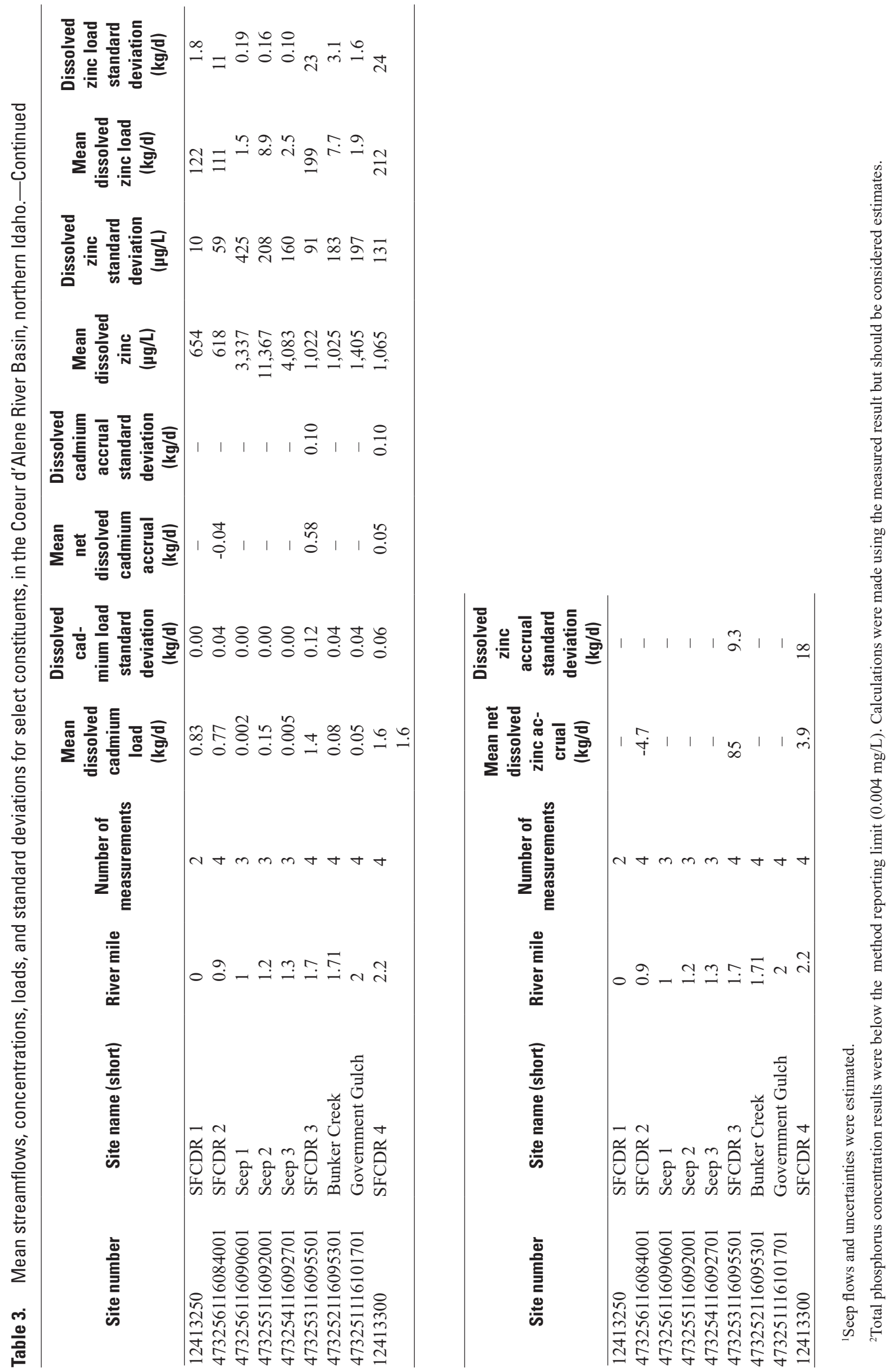

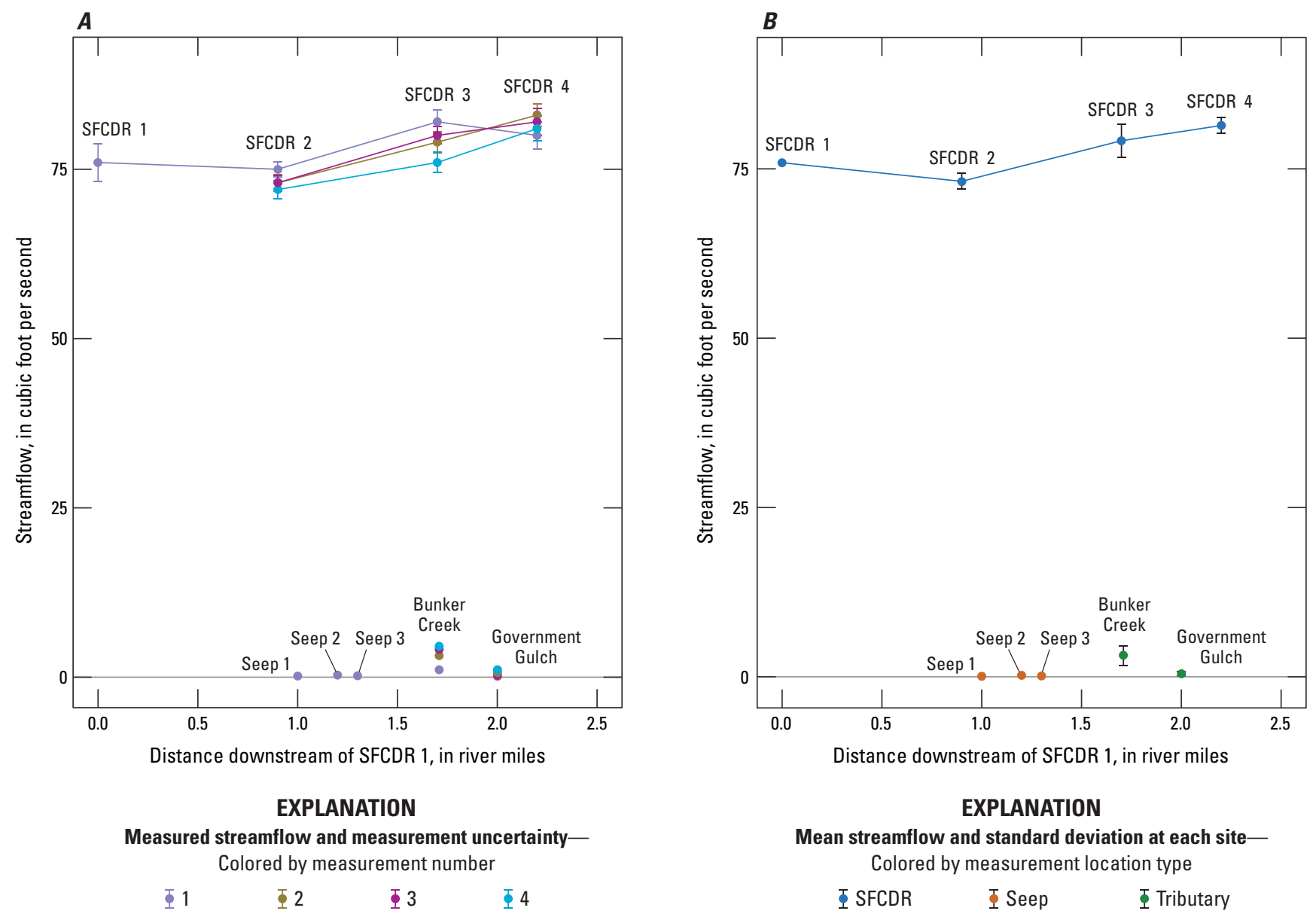

Figure 2. Streamflow accruals as $(A)$ streamflow measurement and uncertainty, and $(B)$ mean streamflow and standard deviation, in the South Fork Coeur d'Alene River (SFCDR), northern Idaho. Error bars are not visible for some points with low values.

\section{Zinc and Cadmium}

Dissolved zinc concentrations and loads increased from upstream to downstream in the SFCDR by about 1.5 to 2 times (table 2). The largest zinc load accrual was calculated between SFCDR 2 and SFCDR $3(85 \pm 9.3 \mathrm{~kg} / \mathrm{d}$, mean \pm standard deviation; table 3 and fig. 3 ). In contrast, a small net zinc loss was calculated between SFCDR 1 and SFCDR $2(-4.7 \mathrm{~kg} / \mathrm{d}$, insufficient measurements at SFCDR 1 to calculate standard deviation). Both net losses and gains were determined in various runs between SFCDR 3 and SFCDR 4 , and the standard deviation exceeded the mean accrual in this stretch $(3.9 \pm 18 \mathrm{~kg} / \mathrm{d}$; table 3 and fig. 3$)$, indicating that accrual between SFCDR 3 and SFCDR 4 cannot be reliably calculated. As with streamflow, zinc load accrual results indicated that the major zone of zinc accrual is between SFCDR 2 and SFCDR 3, and that most of this zinc loading occurred through groundwater inputs and (or) diffuse seepage rather than through discrete seep discharge.
The zinc AWQC ratio increased from SFCDR 1 (4.3) to SFCDR 3 (6.2), and then decreased at SFCDR 4 (5.2; table 4). Hardness increased from upstream to downstream in the SFCDR (68-108 $\mathrm{mg} / \mathrm{L}$ as $\mathrm{CaCO} 3)$, but the biggest increase occurred from SFCDR 3 to SFCDR 4 (77-108 mg/L). Thus, inputs from Bunker Creek (hardness $901 \mathrm{mg} / \mathrm{L}$ ) raised hardness in the SFCDR and correspondingly increased the hardness-dependent zinc AWQCs, which in turn decreased the AWQC ratios slightly at SFCDR 4 (table 4).

Zinc concentrations were measured three times over a period ranging from about 5 to 6.5 hours at three SFCDR sites and two tributaries on September 7, 2017. At each site, the highest concentrations were measured at the earliest sample collection time (fig. 4). The biggest changes in concentration (about 20 percent) were measured in SFCDR 2, SFCDR 3, and in Government Gulch. Very little change in concentrations was measured in SFCDR 4 (2 percent) and in Bunker Creek $(<1$ percent; fig. 4). Therefore, diel effects on zinc concentrations were more pronounced at some sites than others. 


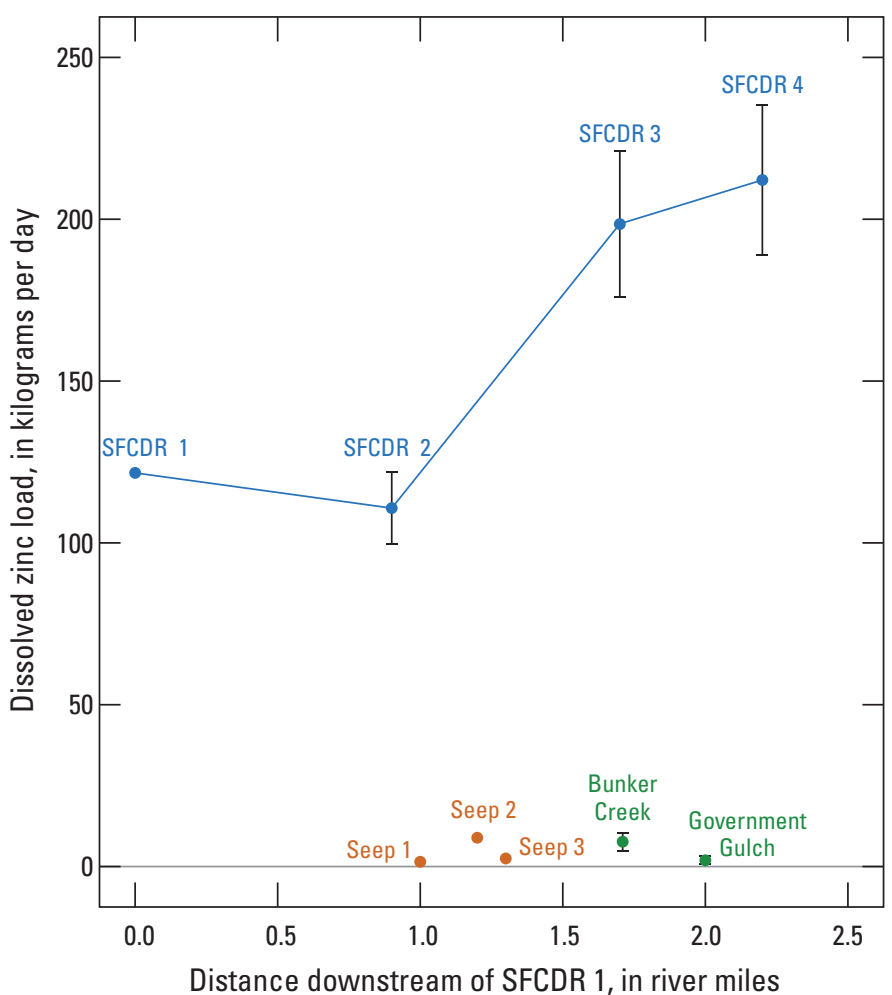

EXPLANATION

Mean load and standard deviation

$\Phi$ SFCDR $\Phi$ Seep $\Phi$ Tributary

Figure 3. Mean dissolved zinc load accruals in the South Fork Coeur d'Alene River (SFCDR), northern Idaho. Error bars represent standard deviations and circles represent means. Error bars are not visible for some points with low standard deviations.

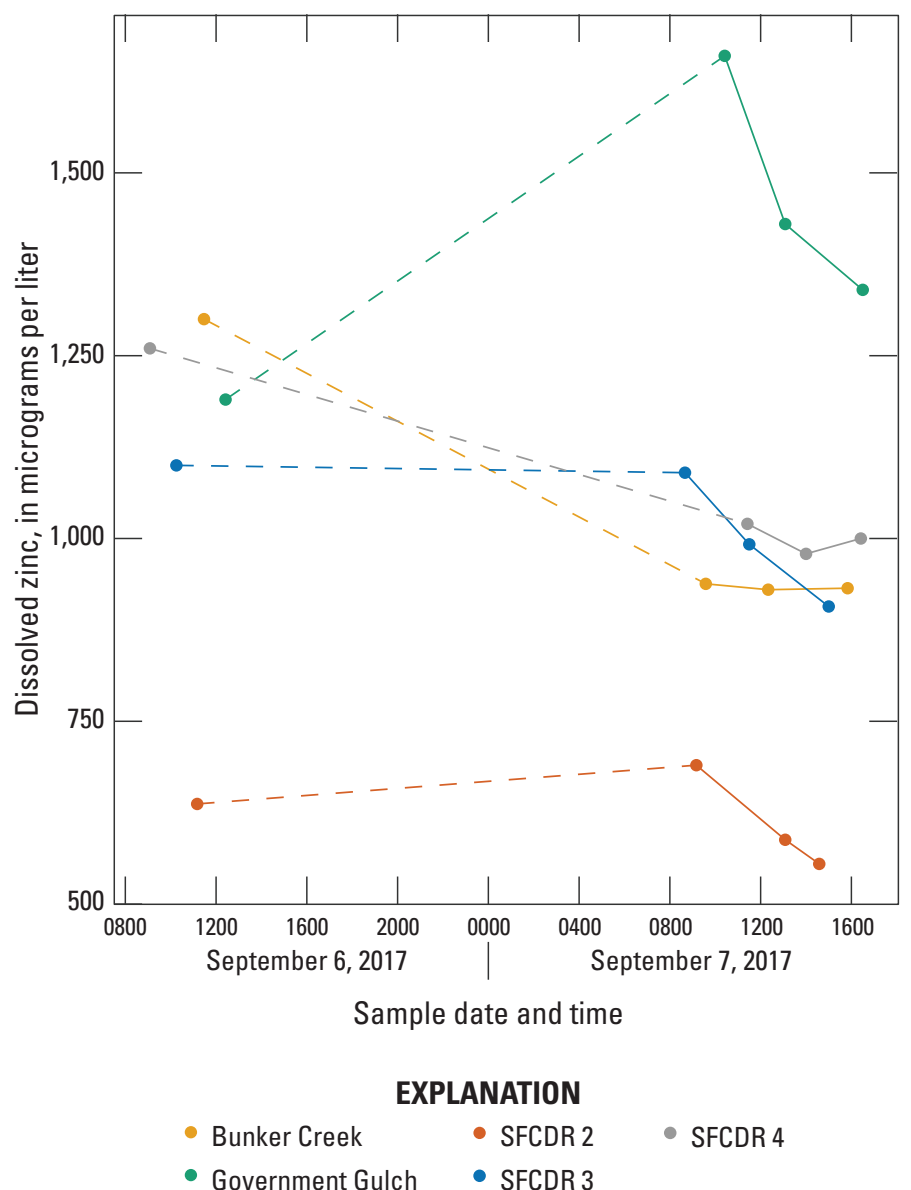

Figure 4. Dissolved zinc concentrations over time in the South Fork Coeur d'Alene River (SFCDR) and tributaries, northern Idaho, September 6-7, 2017. Dashed lines are used where data are not available to show expected daily concentration fluctuations.

Table 4. Summary of site-specific zinc and cadmium ambient water-quality criteria and ratios, in the South Fork Coeur d'Alene River (SFCDR) and select tributaries, northern Idaho.

[AWQC ratios for seeps are shown for comparative purposes only. Abbrevations: AWQC, chronic ambient water-quality criteria; SFCDR, South Fork Coeur d'Alene River; $\mu \mathrm{g} / \mathrm{L}$, microgram per liter; $\mathrm{mg} / \mathrm{L}$ as $\mathrm{CaCO}_{3}$, milligram per liter as calcium carbonate]

\begin{tabular}{|c|c|c|c|c|c|c|c|c|c|}
\hline Site number & Site name & $\begin{array}{l}\text { River } \\
\text { mile }\end{array}$ & $\begin{array}{c}\text { Mean } \\
\text { hardness } \\
\text { (mg/L as } \\
\mathrm{CaCO}_{3} \text { ) }\end{array}$ & $\begin{array}{c}\text { Mean } \\
\text { dissolved } \\
\text { cadmium } \\
(\mu \mathrm{g} / \mathrm{L})\end{array}$ & $\begin{array}{c}\text { Cadmium } \\
\text { AWOC } \\
\text { ( } \mu \mathrm{g} / \mathrm{L})\end{array}$ & $\begin{array}{c}\text { Cadmium } \\
\text { AWQC } \\
\text { ratio }\end{array}$ & $\begin{array}{c}\text { Mean } \\
\text { dissolved } \\
\text { zinc } \\
(\mu \mathrm{g} / \mathrm{L})\end{array}$ & $\begin{array}{l}\text { Zinc } \\
\text { AWOC } \\
(\mu \mathrm{g} / \mathrm{L})\end{array}$ & $\begin{array}{c}\text { Zinc } \\
\text { AWOC } \\
\text { ratio }\end{array}$ \\
\hline 473256116084001 & SFCDR 2 & 0.9 & 69 & 4.29 & 0.78 & 5.5 & 618 & 152 & 4.1 \\
\hline 473256116090601 & Seep 1 & 1 & 172 & 3.42 & 1.54 & 2.2 & 3,337 & 279 & 12 \\
\hline 473253116095501 & SFCDR 3 & 1.7 & 77 & 7.13 & 0.85 & 8.4 & 1,022 & 164 & 6.2 \\
\hline 473252116095301 & Bunker Creek & 1.71 & 901 & 9.82 & 2.87 & 3.4 & 1,025 & 489 & 2.1 \\
\hline 473251116101701 & Government Gulch & 2 & 37 & 40 & 0.49 & 81 & 1,405 & 101 & 14 \\
\hline 12413300 & SFCDR 4 & 2.2 & 108 & 7.82 & 1.09 & 7.2 & 1,065 & 205 & 5.2 \\
\hline
\end{tabular}


Like dissolved zinc concentrations and loads, dissolved cadmium concentrations and loads increased between 1.5 and 2 times from upstream to downstream in the SFCDR (table 2). The largest increase occurred between SFCDR 2 and SFCDR $3(0.58 \pm 0.10 \mathrm{~kg} / \mathrm{d}$, mean \pm standard deviation; tables 2 and 3 , fig. 5). A small net decrease in load was calculated between SFCDR 1 and SFCDR $2(-0.04 \mathrm{~kg} / \mathrm{d})$, and a small mean net increase $(0.05 \mathrm{~kg} / \mathrm{d})$ that was less than the standard deviation $( \pm 0.10 \mathrm{~kg} / \mathrm{d})$ occurred between SFCDR 3 and SFCDR 4.

The cadmium AWQC ratio increased from SFCDR $1(5.8)$ to SFCDR 3 (8.4) and then decreased at SFCDR 4 (7.2; table 4). As with zinc, this decrease was caused by the substantial increase in hardness in the SFCDR from the Bunker Creek inflow.

Cadmium concentrations measured three times on September 7, 2017, showed patterns like those of zinc. Cadmium concentrations decreased between the first and last measurements in SFCDR 2, SFCDR 3, and Government Gulch (fig. 6), which is consistent with expected diel effects on cadmium (Nimick and others, 2003). In contrast, concentrations increased somewhat in SFCDR 4 and Bunker Creek (fig. 6). Therefore, diel effects on cadmium concentrations occurred at some sites but not others.

Streamflows (and, therefore, zinc and cadmium loads in Bunker Creek and Government Gulch) fluctuated substantially during the 2017 study, with metal loads varying by a factor of 3 in Bunker Creek and by a factor of 10 in Government Gulch (table 2). The fluctuations in Bunker Creek were assumed to be driven by changes in operations at the Central Treatment Plant. The changes in Government Gulch likely were related to construction activities observed to be occurring near the creek. However, despite these relatively large shifts in tributary loads, the mean total tributary loads (dissolved cadmium $0.13 \pm 0.07 \mathrm{~kg} / \mathrm{d}$, dissolved zinc $9.6 \pm 4.3 \mathrm{~kg} / \mathrm{d}$ ) were small relative to the metal accruals from groundwater (dissolved cadmium $0.53 \pm 0.10 \mathrm{~kg} / \mathrm{d}$, dissolved zinc $85 \pm 9.3$ $\mathrm{kg}$; table 3).

\section{Total Phosphorus}

Total phosphorus concentrations increased about 10 times from below the method reporting limit at SFCDR 1 and SFCDR $2(<0.004 \mathrm{mg} / \mathrm{L}$ ) to SFCDR 3 (mean 0.037 $\mathrm{mg} / \mathrm{L}$ ) and SFCDR 4 (mean $0.038 \mathrm{mg} / \mathrm{L}$; table 3). Phosphorus accrual increased $(6.3 \pm 0.45 \mathrm{~kg} / \mathrm{d}$, mean \pm standard deviation) between SFCDR 2 and SFCDR 3 (table 3, fig. 7). A small mean net loss $(-0.05 \mathrm{~kg} / \mathrm{d})$ was calculated between SFCDR 1 and SFCDR 2, and after accounting for tributary inputs there also was a small mean net loss $(-0.76 \pm 0.31 \mathrm{~kg} / \mathrm{d})$ between SFCDR 3 and SFCDR 4 (table 3, fig. 7).

The seeps were highly variable in total phosphorus concentrations, ranging from $0.008 \mathrm{mg} / \mathrm{L}$ at Seep 1 to 1.23 $\mathrm{mg} / \mathrm{L}$ at Seep 2 (table 3). However, most of the phosphorus load accrual in the SFCDR could not be accounted for by discrete seep discharge or tributaries. As with streamflow, zinc, and cadmium, most of the phosphorus load accrual occurred between SFCDR 2 and SFCDR 3 and was attributed to groundwater and (or) unmeasured, diffuse marsh inputs.
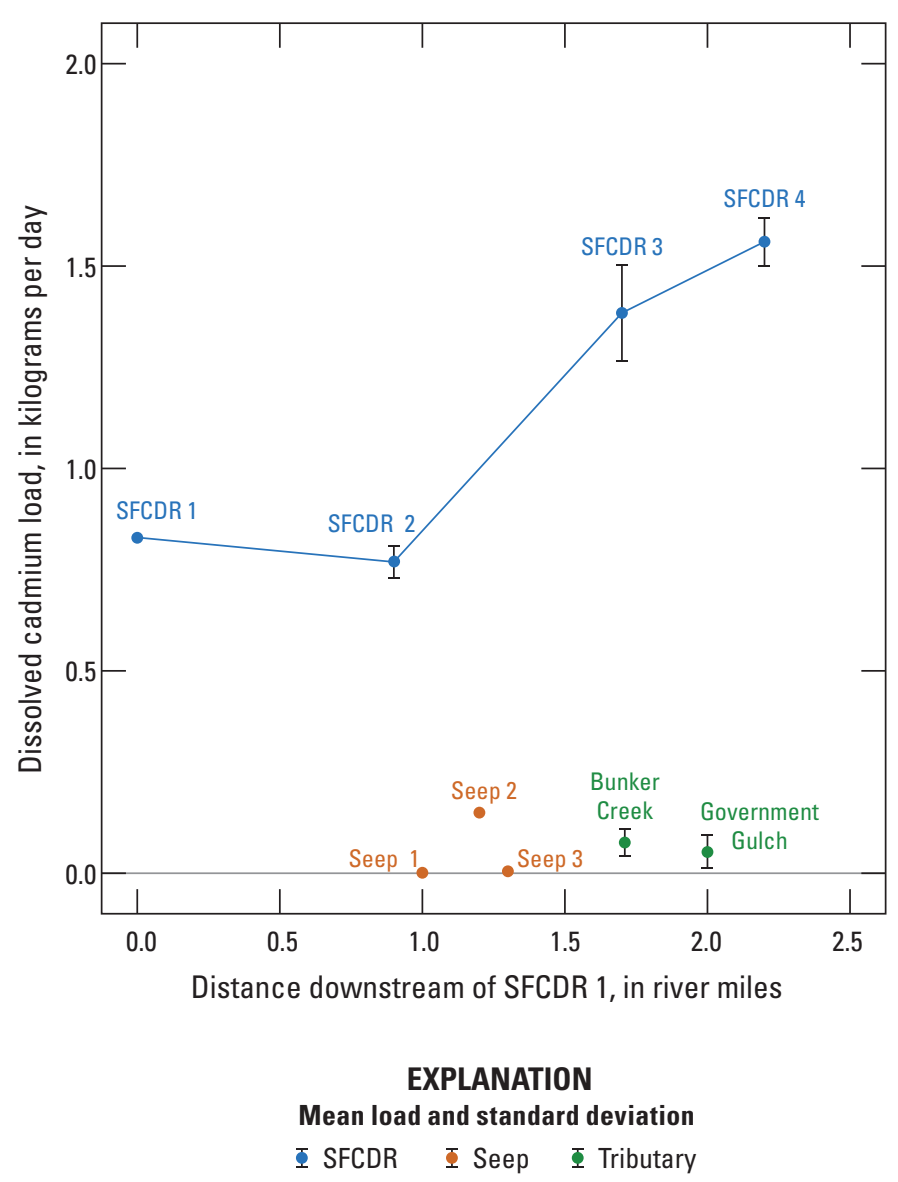

Figure 5. Mean dissolved cadmium load accruals in the South Fork Coeur d'Alene River (SFCDR), northern Idaho. Error bars represent standard deviations and circles represent means. Error bars are not visible for some points with low standard deviations. 


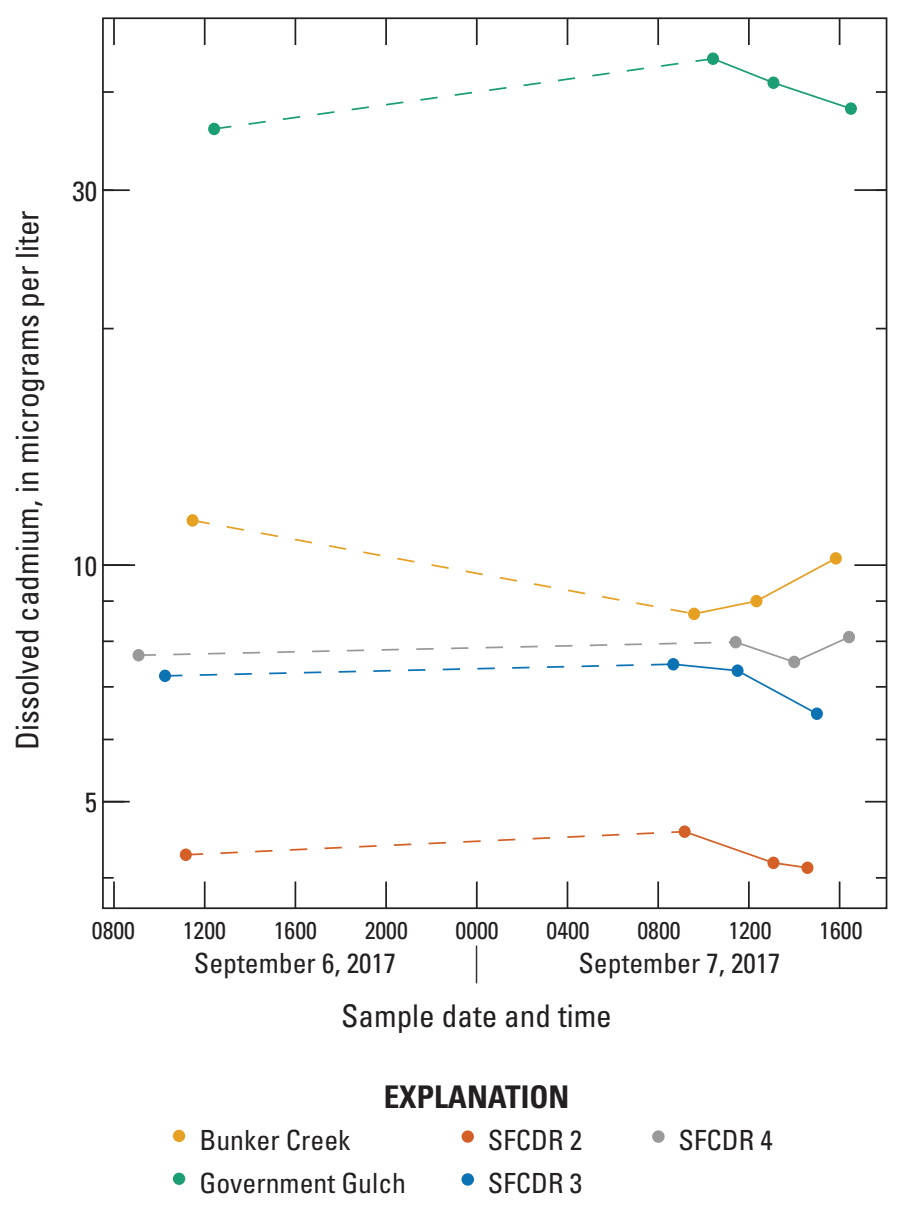

Figure 6. Dissolved cadmium concentrations over time in the South Fork Coeur d'Alene River (SFCDR) and tributaries, northern Idaho, September 6-7, 2017. Dashed lines are used where data are not available to show expected daily concentration fluctuations.

\section{Other Constituents}

Many constituents besides total phosphorus and dissolved zinc and cadmium were measured in the SFCDR, tributaries, and seeps during the seepage study. These data are available through the USGS National Water Information System web interface, https://waterdata.usgs.gov/nwis (U.S. Geological Survey, 2019). Selected examples of these available data, shown as concentrations from upstream to downstream in the SFCDR for select constituents, are displayed in figure 8. Some constituents, such as dissolved arsenic, manganese, and orthophosphate, have trends like those of total phosphorus and dissolved zinc and cadmium. For these constituents, concentrations increased from upstream to downstream, with the greatest change occurring between SFCDR 2 and SFCDR 3 (fig. 8). This pattern indicated that these constituents were present in groundwater inputs. A couple of constituents

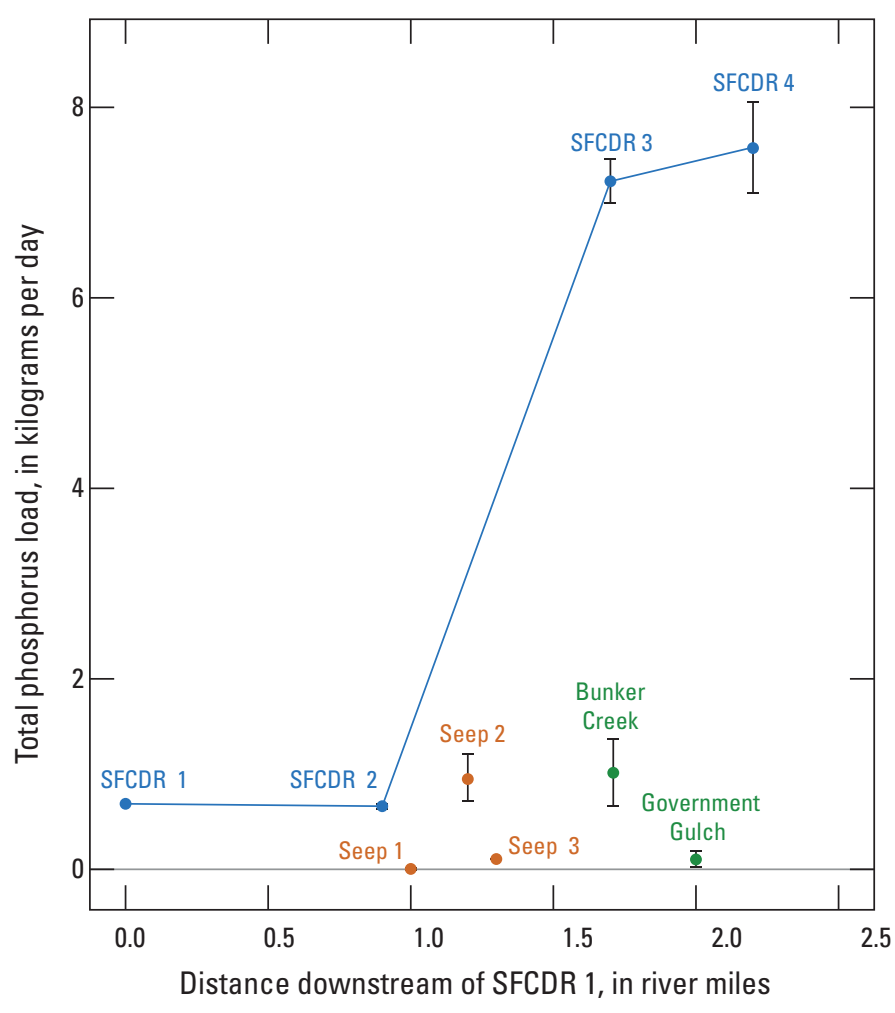

\section{EXPLANATION \\ Mean load and standard deviation \\ I SFCDR $\Phi$ Seep $\Phi$ Tributary}

Figure 7. Mean total phosphorus load accruals in the South Fork Coeur d'Alene River (SFCDR), northern Idaho. Error bars represent standard deviations and circles represent means. Error bars are not visible for some points with low standard deviations.

(dissolved iron and copper) increased between SFCDR 2 and SFCDR 3 before decreasing at SFCDR 4. The increase at SFCDR 3 indicated groundwater was the source of these constituents, but the decrease at SFCDR 4 likely represented instream geochemical changes. Specifically, high dissolved ferrous iron in the relatively lower $\mathrm{pH}$ groundwater (5.8-6.2) enters the relatively higher $\mathrm{pH} \operatorname{SFCDR}(7.7)$, is oxidized and precipitates, potentially as ferrihydrite, and adsorbs copper (Smith, 1999; Balistrieri and others, 2003). A couple of constituents showed the greatest change downstream of Bunker Creek (hardness and specific conductance), indicating the importance of this tributary to these constituents (fig. 8). Finally, other constituents decreased from upstream to downstream (dissolved lead), showed little change (total nitrogen), and (or) had high variability in the downstream reaches (dissolved lead, total nitrogen). These occurrences indicated that groundwater influx was not the dominant control for these constituents. 

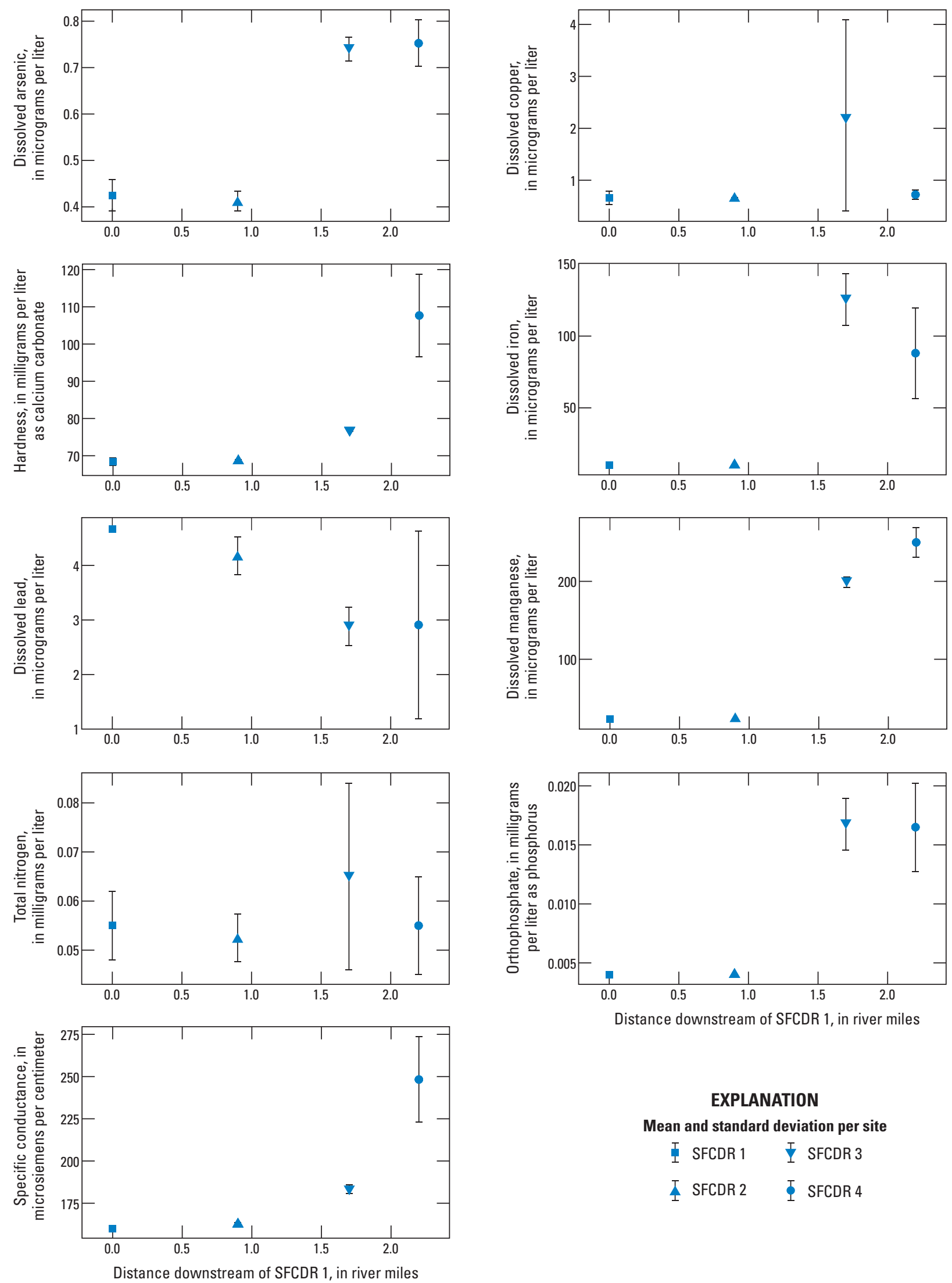

EXPLANATION

Mean and standard deviation per site

I SFCDR 1 I SFCDR 3

I SFCDR 2 † SFCDR 4

Figure 8. Mean constituent concentrations in the South Fork Coeur d'Alene River (SFCDR), northern Idaho. Error bars represent standard deviations and squares, triangles, and circles represent means. Error bars are not visible for some points with low standard deviations. Vertical axis scale and units vary by constituent. 


\section{Discussion}

Streamflow, dissolved zinc and cadmium, and total phosphorus accrual patterns in the SFCDR in September 2017 strongly implicate diffuse groundwater inputs between SFCDR 2 and SFCDR 3. Similarly, these patterns indicate no measurable groundwater or load gain or loss between SFCDR 1 and SFCDR 2, and they indicate greater complexity (gains and losses, high variability) between SFCDR 3 and SFCDR 4. These losing and gaining reaches identified in September 2017 are consistent with those reported in earlier studies.

For example, Barton (2002) identified the reach between SFCDR 1 (Barton site C1.1) and approximately SFCDR 2 (Barton site C3) as neither gaining nor losing in July and September 1999, and as losing in October 1999. The reach between the SFCDR 2 and the SFCDR below Bunker Creek (Barton site C6) was gaining during the three 1999 studies, and the reach downstream of Bunker Creek, including SFCDR 4, was losing during the three studies. CH2M HILL (2009a) identified the reach from SFCDR 1 (CH2M HILL site BH-SF-LF-0003) to approximately above the confluence of Bunker Creek (CH2M HILL site BH-SF-LF-0006) as gaining and identified the reach downstream of Bunker Creek (including SFCDR 4) as losing. Furthermore, groundwater modeling results show a losing reach in the SFCDR until just downstream of Kellogg, and then indicate a gaining reach until just downstream of Bunker Creek, after which the SFCDR becomes a losing stream again (CH2M, 2018). Thus, although high variability in streamflow and constituent accruals calculated between SFCDR 3 and SFCDR 4 in this study limit interpretation, based on previous studies, this reach likely is a losing reach.

Groundwater discharge to the SFCDR generally has been assumed to occur in the SFCDR riverbed (Barton, 2002; CH2M HILL, 2009a). However, the occurrence of a marshy area adjacent to the gaining reach, whose location is congruent with groundwater discharge model results, suggests that groundwater discharge likely occurs to the active channel of the SFCDR as well as to the adjacent marshy area. In either case, the seepage study results indicate that this groundwater discharge is largely diffuse (not captured by discrete measured seeps). Overall, the gaining and losing reaches identified in the 2017 seepage study are consistent with previous results representing conditions over the last twenty years, and this concurrence indicates that remedial actions occurring in the CIA area over that period have not changed overall patterns of groundwater discharge to and recharge from the SFCDR.

Generally, the zinc, cadmium, and phosphorus load accruals from groundwater adjacent to the CIA in September 2017 are similar to or less than those reported in previous studies. Barton (2002) measured the highest dissolved zinc and second-highest dissolved cadmium accruals, averaging 560 and $1.7 \mathrm{lb} / \mathrm{d}$, respectively, during three seepage studies conducted in 1999 (table 5). These accruals are substantially higher than those measured in September 2017 (187 lb/d dissolved zinc and $1.3 \mathrm{lb} / \mathrm{d}$ dissolved cadmium), and higher than most of those measured in seepage studies conducted by CH2M HILL (2009a) from 2003 to 2008 (140-315 lb/d dissolved zinc and 0.80-2.4 lb/d dissolved cadmium; table 5). Variability between the CH2M HILL studies was attributed to variable flow conditions, with heavy precipitation during the 2008 study producing the highest zinc and cadmium loads (315 and $2.4 \mathrm{lb} / \mathrm{d}$, respectively). However, the overall decrease reported between 1999 and the subsequent studies may be caused by the numerous remedial actions occurring in the study area in the late 1990s and early 2000s. These actions included the closure and capping of the CIA (started in August 1999 and completed in November 2000) with a geomembrane to cut off infiltration and numerous source removals, bank and floodplain stabilizations, and land revegetation projects (U.S. Environmental Protection Agency, 2012b). Alternately, there was significant remediation work to remove in-river tailings in the SFCDR and tributaries during summer and fall of 1999, and although care was taken to avoid conducting seepage studies during remedial work days (Barton 2002), it is possible that impacts from the remediation may have affected the 1999 results.

Table 5. Summary of seepage study dissolved zinc and cadmium and total phosphorus load accruals from groundwater, 1999-2017.

[1999: Barton, 2002. 2003-08: CH2MHILL, 2009b. 2017: This study, Zinsser, 2019. All measurements are in pounds per day. Symbol: -, no data]

\begin{tabular}{cccc}
\hline Calendar year & $\begin{array}{c}\text { Total } \\
\text { phosphorus } \\
\text { load }\end{array}$ & $\begin{array}{c}\text { Dissolved } \\
\text { cadmium load }\end{array}$ & $\begin{array}{c}\text { Dissolved } \\
\text { zinc load }\end{array}$ \\
\hline 1999 & - & 1.7 & 560 \\
2003 & - & 1.4 & 157 \\
2006 & - & 0.90 & 140 \\
2007 & - & 0.80 & 142 \\
2008 & 18 & 2.4 & 315 \\
2017 & 14 & 1.3 & 187 \\
\hline
\end{tabular}

Diel fluctuations in dissolved zinc and cadmium concentrations were detected in SFCDR 2, SFCDR 3, and in Government Gulch. Consistent with previous studies, the highest concentrations were measured in the morning and the lowest concentrations were measured in the late afternoon (Nimick and others, 2003; CH2M HILL, 2009b). The 10-20 percent change in cadmium and zinc (respectively) measured in September 2017 was similar to the 9-23 percent change reported by CH2M HILL (2009b) upstream of the study area, but less than the 58-63 percent reported by Nimick and others (2003) downstream of the study area. Extremely smoky conditions in September 2017 may have reduced the photosynthetic activity that drives $\mathrm{pH}$ changes affecting metal concentrations (Nimick and others, 2003; Nimick and others, 2011). In the locations that had no diel fluctuation in zinc and cadmium (SFCDR 4 and Bunker Creek), photosynthesis 
possibly was less important in controlling stream $\mathrm{pH}$ than other factors. Bunker Creek, for example, currently (2019) receives treated mine water discharge from the Central Treatment Plant that causes high hardness (table 4) and likely affects $\mathrm{pH}$. However, diel effects in this study may have been muted by a later sampling time ( 0830 hours) than the time of maximum concentrations reported by previous studies ( 0500 0800 hours in Nimick and others, 2003; 0645 hours in CH2M Hill, 2009b). Nonetheless, the occurrence of diel fluctuations at some sites supports the appropriateness of using site means and standard deviations to analyze and interpret metal accruals in each reach.

Limited previous data are available for total phosphorus loading in the study reach. Clark and Mebane (2014) calculated annual phosphorus loads for water years ${ }^{1} 2009-13$ and reported that loads approximately double in the SFCDR between Kellogg and Smelterville. Although these annual load estimates are not directly comparable to the 2017 seepage study results because they encompass multiple hydrologic conditions (for example, winter flooding, and spring runoff) and multiple loading mechanisms (for example, tributaries, stormwater runoff, and groundwater), they indicate that the phosphorus loading measured in September 2017 is consistent with the longer-term (2009-13) annual conditions.

The 2008 CH2M HILL study measured $18 \mathrm{lb} / \mathrm{d}$ total phosphorus load accrual between Kellogg and Bunker Creek (CH2M HILL, 2009a), compared with $14 \mathrm{lb} / \mathrm{d}$ total phosphorus load accrual in the 2017 seepage study (table 5). As described earlier in this "Discussion" section, the 2008 study encountered heavy rain, which may have contributed to higher phosphorus loads than in the 2017 study. However, the 2008 and 2017 results for this reach are still broadly similar, indicating that base-flow phosphorus loading from groundwater was similar during both studies. Net phosphorus load losses downstream of Bunker Creek, as measured in September 2017, could indicate losing conditions. However, phosphorus is not conservative, and field observations during the seepage study indicated high periphyton growth in the SFCDR downstream of Bunker Creek. Thus, total phosphorus losses in this reach also could be affected by instream cycling of nutrients.

The AWQC ratios for cadmium and zinc are similar to ratios reported in the 2008 seepage study (CH2M HILL, 2009a) and in the USGS trends report (Clark and Mebane, 2014), although neither study is ideal for comparison (table 6). In the 2008 seepage study, cadmium and zinc AWQC ratios were 5.1 and 3.6, respectively, at SFCDR 1 and 7.3 and 6.0 at SFCDR 3 (CH2M HILL, 2009a). These ratios are somewhat lower than those calculated for the 2017 seepage study, in which cadmium and zinc ratios were 5.8 and 4.3 , respectively, at SFCDR 1 and 8.4 and 6.2 at SFCDR 3 (table 6). However, as noted earlier in this "Discussion" section, a substantial

${ }^{1}$ The 12-month period from October 1 , for any given year, through September 30, of the following year. The water year is designated by the calendar year in which it ends. precipitation event occurred during the 2008 seepage study and such events can lower AWQC ratios by lowering the concentration of metals (albeit increasing total loads) in the stream.

Clark and Mebane (2014) reported AWQC ratios for cadmium and zinc of 5.6 and 4.4, respectively, at SFCDR 1 and 7.5 and 5.3, respectively, at SFCDR 4. These ratios are similar to those calculated for the 2017 seepage study, where cadmium and zinc AWQC ratios were 5.8 and 4.3, respectively, at SFCDR 1 and 7.2 and 5.2, respectively, at SFCDR 4 (table 6). However, the ratios reported by Clark and Mebane (2014) represent annual averages, which incorporate data over a range of hydrological conditions from water years 2009-13, and the authors also report decreasing AWQC ratios in the SFCDR during 1993-2013. Base-flow conditions generally produce the highest AWQC ratios because instream zinc and cadmium concentrations are highest during this period (U.S. Geological Survey, 2019). As the average annual ratios reported by Clark and Mebane (2014) are similar to those measured during 2017 base-flow conditions, this may indicate that AWQC ratios have continued to decrease in the SFCDR from 2013 to 2017. However, a more comprehensive analysis of annual data is needed substantiate this hypothesis.

Table 6. Summary of site-specific zinc and cadmium ambient water-quality criteria and ratios from area studies, 2008-17.

[2008: CH2M HILL, 2009a. 2009-13: Clark and Mebane, 2014. 2017: This study, Zinsser, 2019. Abbrevations and symbol: AWQC, chronic ambient water-quality criteria; SFCDR, South Fork Coeur d'Alene River; - , no data]

\begin{tabular}{|c|c|c|c|}
\hline & 2008 & $2009-13$ & 2017 \\
\hline \multicolumn{4}{|c|}{ Cadmium AWOC } \\
\hline$\overline{\text { SFCDR } 1}$ & 5.1 & 5.6 & 5.8 \\
\hline SFCDR 3 & 7.3 & - & 8.4 \\
\hline SFCDR 4 & - & 7.5 & 7.2 \\
\hline Bunker Creek & 2.3 & - & 3.4 \\
\hline Government Gulch & 134 & - & 81 \\
\hline \multicolumn{4}{|c|}{ Zinc AWOC } \\
\hline SFCDR 1 & 3.6 & 4.4 & 4.3 \\
\hline SFCDR 3 & 6.0 & - & 6.2 \\
\hline SFCDR 4 & - & 5.3 & 5.2 \\
\hline Bunker Creek & 0.9 & - & 2.1 \\
\hline Government Gulch & 21 & - & 14 \\
\hline
\end{tabular}

\section{Summary}

The 2017 seepage study in the South Fork Coeur d'Alene River (SFCDR) between Kellogg and Smelterville, northern Idaho, identified groundwater discharge in the reach between monitoring sites SFCDR 2 and SFCDR 3. This reach had increased streamflow, large increases in dissolved zinc and cadmium and total phosphorus concentrations and loads, and corresponding increases in ambient water-quality criteria 
ratios. The location of groundwater discharge was congruent with the findings of similar seepages studies conducted from 1999 to 2008, suggesting that patterns of base-flow groundwater discharge to and recharge from the SFCDR have remained consistent from 1999 to 2017. The magnitude of dissolved zinc and cadmium load accruals from groundwater decreased from 1999 to 2003 following multiple remedial actions in the study area, including capping the Central Impoundment Area and removing tailings in and next to the river in the study reach. However, the magnitude of dissolved zinc and cadmium load accruals from groundwater were similar from 2003 to 2017, indicating little change in the loading mechanisms during this period. Limited data on total phosphorus accruals from 2008 and 2017 suggest that baseflow loading was similar during the two periods. Construction of a groundwater interception system and water treatment plant upgrades began in 2018 and are anticipated to decrease metal loading from groundwater in the study area upon completion. The effect of this remedial action on metal and nutrient loading in the SFCDR will be assessed by repeating this seepage study and comparing results after construction and optimization is completed.

\section{Acknowledgments}

The author thanks the U.S. Geological Survey (USGS) staff who supported the seepage study data collection, including Deena Green, Keith Hein, Dan Hess, Kevin Kirlin and Chris Mebane. Colleagues Christian Schmidt, Jim Bartolino, Connor Newman (USGS), and Jim Stefanoff (Advisian) provided constructive reviews that improved this report.

\section{References Cited}

Balistrieri, L.S., Box, S.E., and Tonkin, J.W., 2003, Modeling precipitation and sorption of elements during mixing of river water and porewater in the Coeur d'Alene River Basin: Environmental Science and Technology, v. 37, no. 20, p. 4694-4701. [Also available at http://dx.doi. org/10.1021/es0303283.]

Barton, G.J., 2002, Dissolved cadmium, zinc, and lead loads from ground-water seepage into the South Fork Coeur d'Alene River system, northern Idaho, 1999: U.S. Geological Survey Water-Resources Investigations Report 2001-4274. 130 p, https://doi.org/10.3133/wri014274.

CH2M, 2018, Draft final Operable Unit 2 groundwater collection system remedial action effectiveness monitoring plan-Bunker Hill Mining and Metallurgical Complex Superfund Site: Prepared for U.S. Environmental Protection Agency, Region 10, Seattle, Washington, 118 p.
CH2M HILL, 2006, Current status - Conceptual site model, Operable Unit 2, Bunker Hill Mining and Metallurgical Complex Superfund Site: Prepared for U.S. Environmental Protection Agency, Region 10, Seattle, Washington [variously paged].

CH2M HILL, 2009a, OU2 2008 groundwater/surface water interaction monitoring data summary: Prepared for U.S. Environmental Protection Agency, Region 10, Seattle, Washington, $97 \mathrm{p}$.

CH2M HILL, 2009b, 2008 high-flow and low-flow surface water study report- -Upper basin of the South Fork Coeur d'Alene River: Prepared for U.S. Environmental Protection Agency, Region 10, Seattle, Washington, $822 \mathrm{p}$.

Clark, G.M., and Mebane, C.A., 2014, Sources, transport, and trends for selected trace metals and nutrients in the Coeur d'Alene and Spokane River Basins, Idaho, 1990-2013: Scientific Investigations Report 2014-5204. 61 p, https:// doi.org/10.3133/sir20145204.

Clark, G.M., and Perreault, L.M., 2017, Quality assurance project plan (QAPP) for U.S. Geological Survey surface water sampling under the Coeur d'Alene Basin environmental monitoring program at the Bunker Hill Superfund Site - OU2 and OU3: Prepared for: U.S. Environmental Protection Agency, Region 10, Seattle, Washington, $51 \mathrm{p}$.

Idaho Department of Environmental Quality [various dates], Rules of the Department of Environmental Quality-Water quality standards: Idaho Administrative Procedure Act (IDAPA) 58, title 01, chap. 02, accessed August 30, 2019, at https://adminrules.idaho.gov/rules/current/58/580102.pdf.

Idaho Department of Environmental Quality and Coeur d'Alene Tribe, 2009, Coeur d'Alene Lake Management Plan: Idaho Department of Environmental Quality and Coeur d'Alene Tribe, 186 p., accessed August 30, 2019, at https://www.deq.idaho.gov/media/468377-_water_data reports_surface_water_water_bodies_cda_lake_mgmt_ plan_final_2009.pdf.

Kimball, B.A., Runkel, R.L., Walton-Day, K., and Bencala, K.E., 2002, Assessment of metal loads in watersheds affected by acid mine drainage by using tracer injection and synoptic sampling - Cement Creek, Colorado, USA: Applied Geochemistry, v. 17, no. 9, p. 1183-1207. [Also available at https://doi.org/10.1016/S0883-2927(02)00017-3.]

Ku, H.H., 1966, Notes on the use of propagation of error formulas: Journal of Research of the National Bureau of Standards - C Engineering and Instrumentation, v. 70C, no. 4, p. 11. [Also available at https://dx.doi.org/10.6028/ jres.070c.025.] 
Long, K.R., 1998, Production and disposal of mill tailings in the Coeur D'Alene mining region, Shoshone County, Idaho-Preliminary estimates: U.S. Geological Survey Open-File Report 98-595, 14 p., https://doi.org/10.3133/ ofr98595.

Mueller, D.K., Schertz, T.L., Martin, J.D., and Sandstrom, M.W., 2015, Design, analysis, and interpretation of field quality-control data for water-sampling projects: U.S. Geological Survey Techniques and Methods, book 4, chap. C4, 54 p., https://doi.org/10.3133/tm4C4.

Nimick, D.A., Gammons, C.H., Cleasby, T.E., Madison, J.P., Skaar, D., and Brick, C.M., 2003, Diel cycles in dissolved metal concentrations in streams - Occurrence and possible causes: Water Resources Research, v. 39, no. 9, 17 p. [Also available at https://dx.doi.org/10.1029/2002WR001571.]

Nimick, D.A., Gammons, C.H., and Parker, S.R., 2011, Diel biogeochemical processes and their effect on the aqueous chemistry of streams - A review: Chemical Geology, v. 283, nos. 1-2, p. 3-17. [Also available at https://dx.doi. org/10.1016/j.chemgeo.2010.08.017.]

Rantz, S.E., 1982, Measurement and computation of streamflow-Volume 1, Measurement of stage and discharge: Water Supply Paper 2175, 284 p., https://doi. org/10.3133/wsp2175_vol1.

Riggs, H.C., 1972, Low-flow investigations: U.S. Geological Survey Techniques of Water-Resources Investigations, book 4, chap. B1, 18 p., https://doi. org/10.3133/twri04B1.

Simonds, F.W., and Sinclair, K.A., 2002, Surface water-ground water interactions along the lower Dungeness River and vertical hydraulic conductivity of streambed sediments, Clallam County, Washington, September 1999-July 2001: U.S. Geological Survey Water-Resources Investigations Report 2002-4161, 69 p., https://doi.org/10.3133/ wri024161.

Smith, K., 1999, Metal sorption on mineral surfaces-An overview with examples relating to mineral deposits, chap 7 of Reviews in economic geology, v. 6A: Littleton, Colorado, Society of Economic Geologists, Inc., p. 161-182.

Turnipseed, D.P., and Sauer, V.B., 2010, Discharge measurements at gaging stations: U.S. Geological Survey Techniques and Methods, book 3, chap. A8, 87 p., https:// doi.org/10.3133/tm3A8.
U.S. Environmental Protection Agency, 1992, Superfund record of decision - Bunker Hill Mining \& Metallurgical Complex, ID: U.S. Environmental Protection Agency Office of Emergency and Remedial Response, Document EPA/ ROD/R10-92-041, 165 p.

U.S. Environmental Protection Agency, 2002, EPA Superfund record of decision-Bunker Hill Mining \& Metallurgical Complex OU 03, Smelterville, ID: U.S. Environmental Protection Agency, Document EPA/ROD/R10-02/032, 507 p. [Also available at https://nepis.epa.gov.]

U.S. Environmental Protection Agency, 2005, Five-year review report-Second five-year review for the Bunker Hill Mining and Metallurgical Complex Superfund Site, Operable Units 1, 2 and 3, Idaho and Washington: U.S. Environmental Protection Agency, Region 10, Document EPA 910-R-05-006, 488 p.

U.S. Environmental Protection Agency, 2012b, Final focused feasibility study report, Upper basin of the Coeur d'Alene River-Bunker Hill Mining and Metallurgical Complex Superfund site: U.S. Environmental Protection Agency, 628 p.

U.S. Environmental Protection Agency, 2012a, Interim record of decision (ROD) amendment, Upper basin of the Coeur d'Alene River-Bunker Hill Mining and Metallurgical Complex Superfund site: U.S. Environmental Protection Agency, 488 p. [Also available at https://semspub.epa.gov/ work/10/664107.pdf.]

U.S. Geological Survey, 2017, Methods for quantifying streamflow measurement uncertainty for measurements stored in the National Water Information System: U.S. Geological Survey, Office of Surface Water Technical Memorandum 2017.12, 3 p. [Also available at https://water. usgs.gov/admin $/ \mathrm{memo} / \mathrm{SW} / \mathrm{sw} 17.12$.pdf.]

U.S. Geological Survey, 2018, StreamStats-Streamflow statistics and spatial analysis tools for water-resources applications: U.S. Geological Survey water resources database, accessed August 6, 2018, at https://water.usgs. gov/osw/streamstats/index.html.

U.S. Geological Survey, 2019, National Water Information System-Web interface: U.S. Geological Survey web page, https://nwis.waterdata.usgs.gov/nwis.

U.S. Geological Survey [various dates], National field manual for the collection of water-quality data: U.S. Geological Survey Techniques of Water-Resources Investigations, book 9, chaps. A1-A10, http://pubs.water.usgs.gov/twri9A. 
Publishing support provided by the U.S. Geological Survey Science Publishing Network, Tacoma Publishing Service Center

For more information concerning the research in this report, contact the Director, Idaho Water Science Center

U.S. Geological Survey

230 Collins Road

Boise, Idaho 83702-4520

https://www.usgs.gov/centers/id-water 


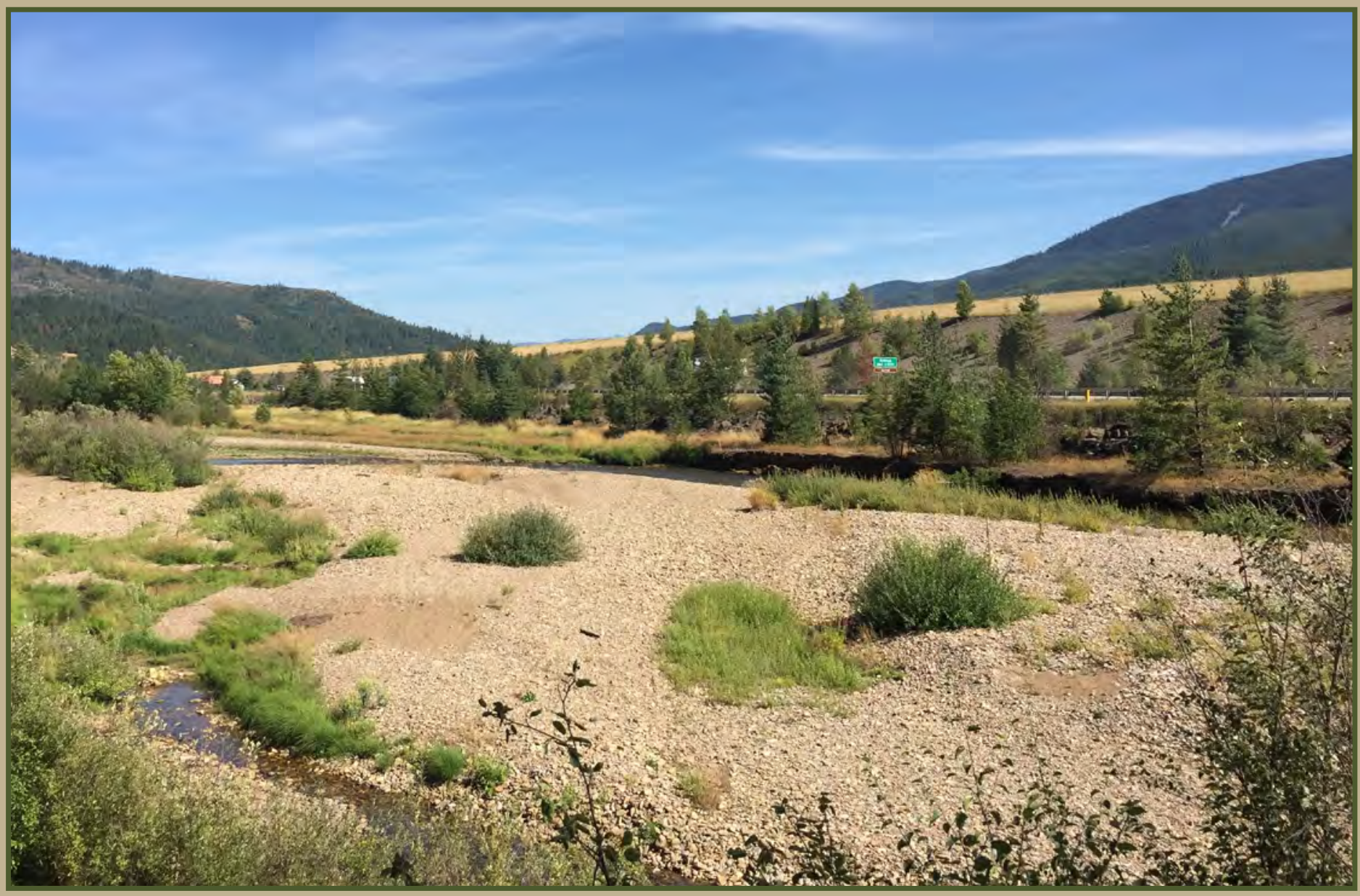

